\title{
Bt cotton, pink bollworm, and the political economy of sociobiological obsolescence: insights from Telangana, India
}

\author{
Katharina Najork $^{1}$ (D) Jonathan Friedrich ${ }^{1,2} \cdot$ Markus Keck $^{3}$
}

Accepted: 18 January 2022 / Published online: 7 February 2022

(c) The Author(s) 2022

\begin{abstract}
After genetically engineered Bt cotton lost its effectiveness in central and southern Indian states, pink bollworm infestations have recently returned to farmers' fields and have substantially shifted their vulnerability context. We conceive Bt cotton as a neoliberal technology that is built to protect farmers only temporarily from Lepidopteran pests while ultimately driving the further concentration of capital. Based on data from a representative survey of the three major cotton-producing districts of the state of Telangana $(n=457)$, we find that pink bollworm pest infestations are a shock to farmers that lead to severe losses in yield and income. Using the vulnerability concept as a framework, we embed our findings in a political-economic context by drawing on Harvey's notion of accumulation by dispossession. We argue that Bt cotton includes an inherent sociobiological obsolescence that results in a systematic dispossession of resource-poor households while providing appropriation opportunities for other actors. Finally, reproduced hegemonic structures facilitate the accumulation of capital through a redistribution of assets from the bottom to the top of the agricultural sector. Claims that considered Bt cotton as a pro-poor technology were thus flawed from the outset.
\end{abstract}

Keywords Biotechnology $\cdot$ Capitalism $\cdot$ Food regime analysis $\cdot$ Livelihood $\cdot$ Resilience $\cdot$ Socionatures

$\begin{array}{ll}\text { Abbreviations } \\ \mathrm{Bt} & \text { Bacillus thuringiensis } \\ \mathrm{PBW} & \text { Pink bollworm } \\ \mathrm{HHs} & \text { Households } \\ \text { HT } & \text { Herbicide-tolerant }\end{array}$

Katharina Najork

katharina.najork@uni-goettingen.de

Jonathan Friedrich

Jonathan.Friedrich@zalf.de

Markus Keck

markus.keck@uni-a.de

1 Institute of Geography, University of Göttingen, Goldschmidtstr. 5, 37077 Göttingen, Germany

2 Leibniz Centre for Agricultural Landscape Research (ZALF), Eberswalder Str. 84, 15374 Müncheberg, Germany

3 Chair for Urban Climate Resilience, Centre for Climate Resilience, University of Augsburg, 86159 Augsburg, Germany

\section{Introduction}

Since its commercialization in India in 2002, genetically engineered $\mathrm{Bt}$ (Bacillus thuringiensis) cotton has been subject to controversial scientific and public debate (Qaim 2003; Stone 2011; Kathage and Qaim 2012; Choudhary and Gaur 2015; Gutierrez et al. 2015; Kranthi 2015; Veettil et al. 2016; Flachs 2019a). This controversy around $\mathrm{Bt}$ technology has been reignited by the recent reoccurrence of pink bollworm (PBW) pest infestations in several central and southern Indian cotton-producing states, such as Gujarat, Madhya Pradesh, Maharashtra, Karnataka, Andhra Pradesh, and Telangana (Mohan 2017; Naik et al. 2018; Fand et al. 2019). As the bollworm complex ${ }^{1}$ accounts for major limitations in the global production of cotton, controlling the threat associated with these borer insects is considered a primary objective in cotton-producing sectors worldwide (Naik et al. 2005; Choudary and Gaur 2015; Kaviraju et al. 2018; Fand et al. 2019). This is especially true for India, which is the leading producer of cotton worldwide and contributes a quarter of the global production, which is cultivated by 7.7 million smallholders (Choudhary and Gaur 2015; Shahbandeh 2019).

\footnotetext{
${ }^{1}$ Aside from the PBW (Pectinophora gossypiella), the bollworm complex includes the American bollworm (Helicoverpa armigera) and the spotted bollworm (Earias vitella).
} 
In this context, Bt cotton, with its integrated pest protection ability, has been heralded as a silver bullet by proponents of Bt technology in the fight against this key pest affecting cotton production for years. Equipped with genes of the $\mathrm{Bt}$ bacterium, Bt cotton plants produce endotoxins that are lethal to some Lepidopteran pests, such as the PBW (Naik et al. 2005; Subramanian and Qaim 2009; Kathage and Qaim 2012; Kaviraju et al. 2018; Khan et al. 2018). However, the abrupt return of the major cotton pest that Bt technology aimed to prevent has alarmed scientists and policy makers alike and set off a renewed debate regarding the longevity of the technology (Mohan 2017; Naik et al. 2018; Fand et al. 2019; Friedrich et al. 2022; Najork et al. 2021). An earlier wave of this debate occurred when the first Bt cotton generation (Bollgard I) was declared ineffective in 2009 and was soon after replaced by its successor (Bollgard II), which was authorized in India in 2006. Upcoming resistance of the target pest against the singlegene Bt cotton variant was previously reported, and obsolescence was suspected (Haribabu 2014; Naik et al. 2018). The recent return of the PBW has now retriggered these previous concerns. A critical reexamination of the role of $\mathrm{Bt}$ technology, especially in regard to cotton farming households' (HHs) altered vulnerability contexts and the broader related politicaleconomic implementations, is therefore urgently needed.

Our aim is to provide such a reassessment by means of a political-economic discussion of the recent technological failure of Bt cotton in India. Therefore, we follow Flachs (2019a), who postulates a lack of critical understanding of the recurrent crises of Indian Bt cotton cultivation. We present the results of a representative survey of vulnerabilities among Bt cotton-farming HHs in Telangana, India $(n=457)$. While we addressed this issue in a prior qualitative study (Najork et al. 2021), we now aim to contextualize the newly emerged vulnerability context in the broader political economy. We thus tie our vulnerability-related findings to the concept of accumulation by dispossession (Harvey 2005) and argue that $\mathrm{Bt}$ cotton is a neoliberal technology with an inherent sociobiological obsolescence, which leads to a successive dispossession of economically weak farmers and enables the appropriation of agricultural assets by others. This ultimately reproduces prevalent hegemonic structures in a Gramscian sense (Brown 2019; Jakobsen 2018b) and drives capital to further concentrate in India's cotton-producing sector.

\section{Vulnerability, technology and capitalism}

In this study, we provide an analysis of the shift in the vulnerability context of cotton-farming $\mathrm{HH}$ in India due to the recent return of PBW infestations. Vulnerability describes the exposure of HHs to contingencies and stress and the difficulty of coping with and adapting to them (Watts and
Bohle 1993; Adger 2006). Given the background of our study, this concept allows us to examine the state of susceptibility of farming HHs to harm from exposure to PBW pest infestations and from the absence of capacities to cope with and adapt to this altered situation (Adger 2006, p. 268). Our vulnerability analysis involves a discussion of the following four key parameters: $\mathrm{HH}$ exposure and susceptibility to PBW infestations and their coping and adaptation mechanisms (Birkmann 2006; Füssel 2007; Weichselgartner 2016). In terms of exposure, we address the nature and degree to which a $\mathrm{HH}$ experiences environmental and socioeconomic stress, which can be characterised by the frequency, magnitude, and duration of the stress (Adger 2006, p. 270), and under susceptibility, we discuss the extent to which PBW infestations affect the studied HH economies (Weichselgartner 2016, p. 20). In terms of coping, we describe the potential of HHs to immediately deal with and overcome stress related to PBW infestations by means of available resources, knowledge and skills, while in terms of adaptive capacities, we examine HHs' abilities to learn from past experiences and to actively expand their range of options for coping in the near future (Keck and Sakdapolrak 2013, p. 10). Specifically, the following capabilities describe the resilience of a HH system: the capacity to persist when confronted with disturbance; the ability to adapt to political, social, and environmental changes; and the ability to transform to enhance future functionality (Keck and Etzold 2013, p. 77; Folke et al. 2010).

As Watts and Bohle (1993) suggested in their landmark article, vulnerability analyses should account for the structural properties of the political economy, which decisively precipitate livelihood conditions and HHs' capacities to withstand crises. In this study, we take this consideration seriously. We use the vulnerability concept as a heuristic framework to order our results and discuss our findings against the backdrop of the current neoliberal regime, which provides a larger political-economic context in India at present.

Neoliberalism generally involves the politically initiated restructuring of institutional frameworks for intensified marketization and commodification (Harvey 2007; Brenner et al. 2010). Until the early 2000s, neoliberalism was mostly viewed as a totalizing hegemonic structure characterized by a fixed set of attributes with predetermined outcomes that spread across national borders (Ong 2007). In contrast, the contemporary understanding of neoliberalism is more like that of a variegated nexus of constitutively uneven but cumulatively transformative processes and mechanisms (Peck and Theodore 2007; Brenner et al. 2010). Brenner et al. (2010, p. 198) therefore argue that there is no "single worldwide neoliberal regime" but rather hypothesize that successive waves of neoliberal transformation occur at all spatial scales, culminating in "distinct yet interdependent 
pathways of neoliberalization". Accordingly, we understand neoliberalism as a logic of governing that migrates and is selectively taken up in various political contexts (Ong 2007). In this paper, we particularly call attention to the role of technology as one mechanism of the ongoing processes of neoliberalization.

Harvey (2003) describes neoliberal societies as those that tend to follow the belief that there is a technological solution "to whatever problems they are encountering" (Harvey 2003, p. 3, 2007)—a 'technological fix'. In our case, Bt cotton represents one such neoliberal technology. Advocates have argued that $\mathrm{Bt}$ technology not only protects farmers from infestations on an individual scale but also leads to economic growth in the agricultural sector and rural development in India as a whole (Qaim 2003; Kathage and Qaim 2012; Choudhary and Gaur 2015; Veettil et al. 2016). However, as Harvey $(2003,2007)$ shows, technological fixes in general do not truly serve to actually solve the aforementioned economic or societal problems but rather enable further accumulation of capital. In this context, corporate strategies emerge to create new markets that are primarily dedicated to producing new demands for products that hitherto have not existed (Harvey 2007, p. 69). To keep the machinery of creating demands alive, predetermined breaking points are integrated into products such as consumer electronics, clothing, and automobiles, causing obsolescence and, thus, ensuring long-term sales of ever-new products through a shortened product life cycle (Haribabu 2014). The use of inferior materials, for example, can initiate breaking points that force consumers to repeatedly buy new products, while those in prior use can be repaired instead (Haribabu 2014). While this obsolescence is planned and technological in essence, Haribabu (2014) argues that the seed industry also employs such strategies.

Building on Haribabu (2014), in this paper, we argue that Bt cotton seed technology has an underlying obsolescence, which we identify as a sociobiological obsolescence. We use the term sociobiological because the production and use of Bt technology is socially constructed and embedded while concurrently being entangled with biological influences. As the socially anchored technology is rendered obsolete with every newly emergent resistance in the target pest, it is conditional on basic biological developments. The underlying processes that cause $\mathrm{Bt}$ technology to become obsolescent, therefore, markedly differ from those in the manufacturing industry in that they depend on biological qualities. However, we argue that the outcome, i.e., the increased pressure on consumers to buy ever-new products shows clear parallels. While we thus renounce the labelling of this obsolescence as deliberate and hence distinguish it from a 'planned' obsolescence, we suggest that the technological design was flawed from the start, as it has always been dependent on evolutionary biological factors and therefore includes an inherent obsolescence.

In this way, we see the obsolescence built into contemporary Bt technology as a key driver of what Harvey (2005) called 'accumulation by dispossession'. Harvey (2005) draws upon Karl Marx's (1967, p. 714) notion of 'primitive accumulation' but focuses on the new strategies developed in capitalist countries under neoliberal governments aiming to transfer public wealth into an increasingly concentrated private sector. Marx used the concept of primitive accumulation to grasp the precondition of capitalism marked by late sixteenth-century English enclosures in which elites appropriated peasant land to graze sheep and engage in the highly profitable wool trade, while peasant farmers became landless and, thus, were obliged to engage in wage labour (Perelman 2000; Di Muzio 2007). With his reading, he turned especially against the bourgeois mythologies concerning capital being generated through the frugality of the elite, replacing it with a history of violent expropriation, colonial expansion and racialized enslaved labour (Di Muzio 2007; Burnard 2019). However, for Marx, the 'historical process of divorcing the producer from the means of production' was confined to a particular (if indefinite) period before the capitalist accumulation regime fully locked in. In contrast, according to Luxemburg (2003) and Harvey (2005), the violent expropriation of production resources represents a process that is still taking place in capitalist economies to date (Glassman 2006; Castree 2007; Carroll 2017; Rosa et al. 2017). The removal of agricultural producers from the countryside, especially in peripheral regions, and the consolidation of more privatized control over resources remain very important processes today, affecting billions of people, especially in the Global South (cf. Luxemburg 2003). As Harvey shows, primitive accumulation-or its present form of accumulation by dispossession-is an inherent and continuous element of current capitalist societies, and its range of action extends to the entire world (cf. Luxemburg 2003; Glassman 2006; Carroll 2017).

What accumulation by dispossession essentially does is create crises and enforce a devaluation of assets, which can later be seized via capital and turned to profitable use (Harvey 2005, p. 149ff). Thus, recurring crises constitute both an essential feature of capitalism itself and a major instrument for accumulation by dispossession. The state, with its hegemonic licence to define what is legal and what is not, is not simply an accomplice in this process. Rather, the state plays an active role in coordinating new forms of dispossession, in providing normative frameworks that legally support it, and in legitimizing the process of creating dispossessed social actors in the name of growth and progress (Cáceres 2015, p. 117). 


\section{Methodology}

Among Indian cotton-producing states, Telangana ranks third, after Gujarat and Maharashtra, with regard to cotton area and production. In the 2016/17 season, the planting area of cotton in the state was $1.4 \mathrm{Mha}$, and production reached 4.8 million bales, with a yield of $579 \mathrm{~kg} / \mathrm{ha}$ (CCI 2018, p. 3 ). This area is in the southern zone of Indian cotton production and is primarily rainfed (Gaurav and Mishra 2012; Choudhary and Gaur 2015). We chose Telangana because it provides a valid perspective of southeastern Indian rainfed cotton production that contrasts with the perspective of profiting northern irrigated Bt cotton growing states (Gutierrez et al. 2015). In this study, we built upon earlier qualitative research that we conducted in the state and, thus, aimed to complement those findings with the results of a quantitative survey (Najork et al. 2021).

\section{Data acquisition}

We conducted fieldwork in August and September 2019 in 15 randomly selected villages in the three major cotton-producing districts of Telangana, i.e., Adilabad, Warangal, and Nalgonda (Fig. 1). We selected these three districts because they are ranked highest in terms of total cotton area, percentage of area under cotton cultivation to total area sown, and output (Government of Telangana 2017, pp. 118-120). ${ }^{2}$ For each district, we determined the three mandals ${ }^{3}$ with the highest percentage of area under cotton cultivation to the total area sown according to the district's agricultural handbook, which we acquired in person from the relevant agricultural offices (Agricultural Office Adilabad 2014; Agricultural Office Warangal 2014; Agricultural Office Nalgonda 2015). In each mandal, we randomly selected five villages with 1000 to 6000 inhabitants via automated computerized sampling and calculated the sample sizes for each individual village (Table 1) on the basis of available population data from 2011 (Government of India 2011). ${ }^{4}$ We ultimately identified the HHs for the interviews by means of random walks. Each village was defined in its erstwhile boundaries in consultation with local sarpanches and then divided into commensurate areas on the basis of satellite images. Along

\footnotetext{
${ }^{2}$ As we relied on the decennially published Indian census data for our survey sampling method and, thus, used the 2011 census data for our sampling, it was inevitable that all the data used in the sampling procedure refer to the erstwhile districts and village structures of Telangana before they were restructured in 2016.

3 A mandal is the administrative division subordinate to a district.

${ }^{4}$ Our sampling procedure rests on population figures presented in the 2011 census. These figures might deviate from actual proportions as recent population dynamics may have resulted in changes in some of the village sizes.
}

the random walks, we targeted every other house and alternated starting at the village centre or outskirts, aiming to take into account geographically replicated socioeconomic backgrounds (e.g., caste or class) and to avoid biases in the results. A total of $457 \mathrm{HHs}$ were interviewed through their respective $\mathrm{HH}$ heads, which resulted in sex- and agewise bias, since the vast majority of $\mathrm{HH}$ heads was male and 30 years or older. To avoid distorting effects arising from interventions in the interviews by neighbours or relatives, we interviewed the identified $\mathrm{HH}$ heads individually. All interviewees had grown cotton within the last 5 years.

We were accompanied by six Telugu-speaking surveyors who were responsible for data collection. All of them received specific training beforehand on both the thematic focus of the study and its quantitative methodology and took part in test interview scenarios. An intense preparatory phase allowed for an in-depth mutual understanding between the surveyors and the rest of the study team. A pretest was given in two Warangal villages not included in the sample to ensure proper questioning and handling of the questionnaire. The questionnaire included open- and closed-ended questions and Likert-scale, single-choice, and multiple-choice questions. The thematic focuses of the questions included sociodemographic and agriculture-related data, both at the $\mathrm{HH}$ level, as well as data on the cultivation of Bt cotton, PBW, refuge crops, and access to knowledge and markets. Given our theoretical scope, for this study, we consider thematic sections concerning the cultivation of $\mathrm{Bt}$ cotton and PBWs and focus on HHs' economic assets. ${ }^{5}$

As our vulnerability study relies on farmer recall, it is also possibly biased in regard to data that are related to past phenomena. Exaggeration, underestimation, and misremembering facts are common challenges in social sciences research. However, since we did not ask for specific agronomic figures such as yield, prices or income, which farmers often have difficulties supplying (Flachs 2019b), this approach allowed us to record larger trends in Bt cotton production from the farmers' perspective. With this study, we therefore do not aim to and cannot portray aggregate production statistics or yield averages; rather, we attempt to expose the effects of $\mathrm{Bt}$ cotton technology on marginalised farming HHs by depicting the mechanisms of dispossession on a micro scale. While we are aware that a cohort study would provide a much more nuanced picture and allow us to track changes over time, it is in the very nature of the matter that our study covers only a short time frame, since the return of the PBW is a recent phenomenon.

\footnotetext{
${ }^{5}$ We are aware of the potential effects of noneconomic resources (e.g., knowledge, social relations, trust) on farmers' vulnerabilities in regard to the reoccurring target pest; however, this aspect is beyond the scope of this article.
} 

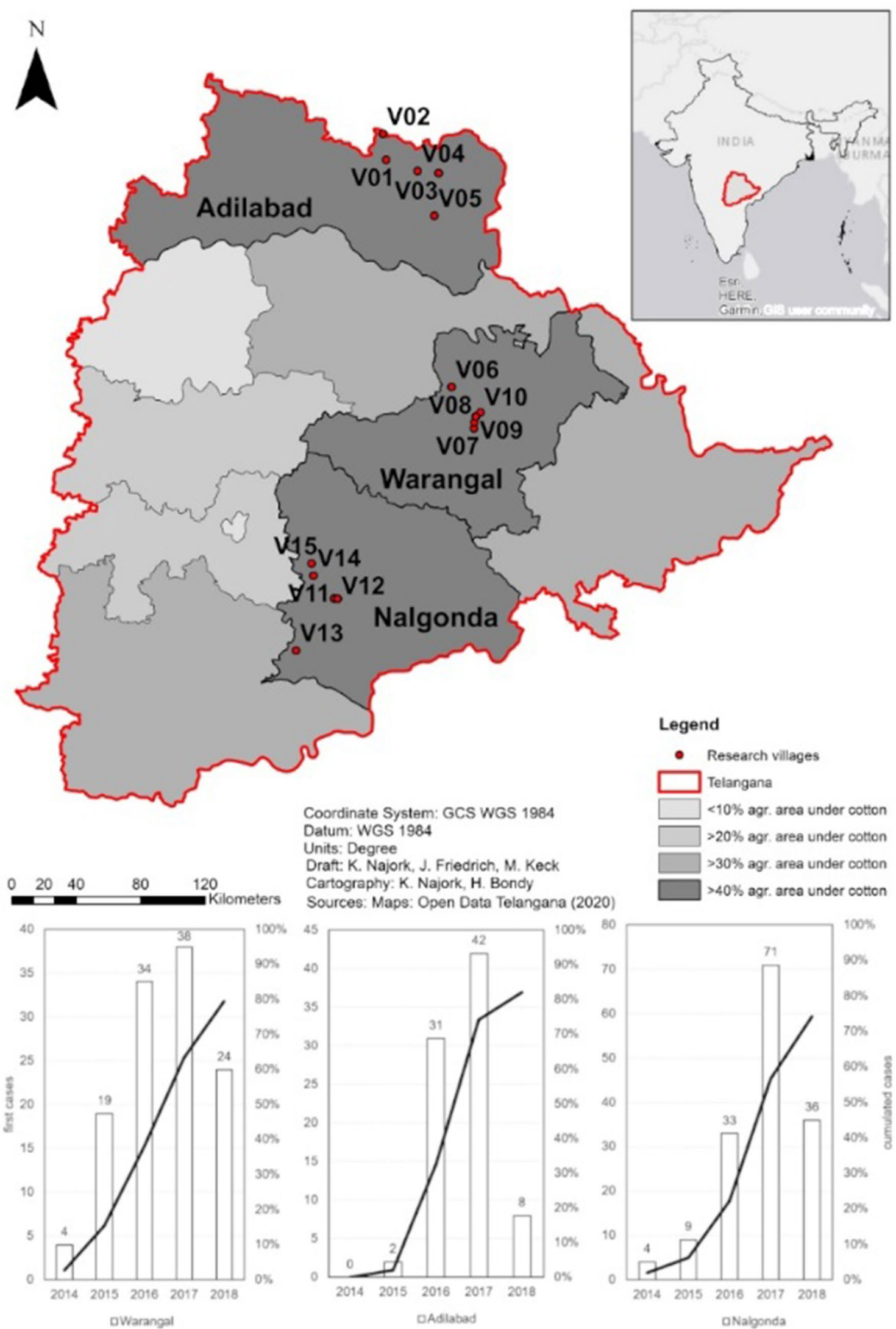

Fig. 1 Cotton production, study sites, and PBW infestation in Telangana 
Table 1 Sample composition

\begin{tabular}{llllll}
\hline District & Mandal & Village & Population & No. HHs & $\mathrm{n}$ \\
\hline Adilabad & Wankdi & 1 & 1009 & 223 & 10 \\
Adilabad & Wankdi & 2 & 1854 & 405 & 18 \\
Adilabad & Kagaznagar & 3 & 2665 & 687 & 31 \\
Adilabad & Kagaznagar & 4 & 2304 & 575 & 26 \\
Adilabad & Bhimini & 5 & 1292 & 344 & 16 \\
Warangal & Parkal & 6 & 3261 & 853 & 38 \\
Warangal & Duggondi & 7 & 3729 & 1026 & 46 \\
Warangal & Duggondi & 8 & 2761 & 743 & 33 \\
Warangal & Duggondi & 9 & 2723 & 730 & 33 \\
Warangal & Duggondi & 10 & 3305 & 953 & 43 \\
Nalgonda & Chandur & 11 & 2907 & 759 & 34 \\
Nalgonda & Chandur & 12 & 2147 & 501 & 23 \\
Nalgonda & Devarakonda & 13 & 2796 & 665 & 30 \\
Nalgonda & Narayanapu & 14 & 5663 & 1415 & 63 \\
Nalgonda & Narayanapur & 15 & 1173 & 288 & 13 \\
\hline
\end{tabular}

\section{Data analysis}

In our analysis, we calculated the correlations of socioeconomic $\mathrm{HH}$ features and basic agricultural characteristics with the impact of PBW pest infestations and recent changes in agricultural production. We examined the frequency distributions of all relevant variables by means of $\chi^{2}$ tests, whereas sparsely populated categories as well as variables with insufficient overall frequencies (cross-tables with $>20 \%$ of cells with expected counts below 5) were excluded. We quantified the identified correlations by Cramer's V $(\varphi)$ (nominal data; $p \leq \alpha \leq 0.05$ ) and Spearman's rank $(\rho)$ correlation (ordinal data; $p \leq \alpha \leq 0.05$ ) coefficients and studied them further on the basis of relevant cross-tabulations (De Lange and Nipper 2018).

\section{Bt cotton in India}

The commercialization of Bt cotton in India has to be observed in the context of the neoliberal economic reforms undertaken in the 1990s. The Indian agricultural sector was restructured, in that state regulations were eased, seed production was privatized, and trade barriers were removed so that agrarian technologies could be accessed more easily from abroad (Glover 2007; Carroll 2017; Flachs 2019a). This restructuring allowed the Indian Maharashtra Hybrid Seeds Company (Mahyco) and the US-based company Monsanto to develop genetically engineered cotton for the Indian market in a joint venture called Mahyco Monsanto Biotech
Limited (MMBL). ${ }^{6}$ Single-gene Bollgard I (Cry1Ac) and double-gene Bollgard II (Cry1 Ac and Cry2Ab) cotton were commercialized in 2002 and 2006, respectively ${ }^{7}$ (Ramamurthy 2000; Scoones 2008; Sadashivappa and Qaim 2009; Flachs 2019a). Given the unprecedented rise in the implementation of this new technology, today, an estimated $95 \%$ of the area under cotton cultivation is planted with doublegene Bt cotton (ISAAA 2017).

However, despite its promising implementation rate, the risks and benefits of the technology remain contested (Qaim 2003; Stone 2011; Kathage and Qaim 2012; Choudhary and Gaur 2015; Gutierrez et al. 2015; Kranthi 2015; Veettil et al. 2016; Flachs 2019a; Kranthi and Stone 2020). In particular, agronomic scholars attribute successes in Indian cotton production in the early 2000s, that is, increased yields and decreased pesticide use, to the technology, thus declaring it an effective weapon against the Indian agrarian crisis (Sadashivappa and Qaim 2009; Kathage and Qaim 2012; Veettil et al. 2016). Other studies, however, accredit these positive agronomic trends to a plethora of factors and emphasize the high variability of the socioeconomic effects of the technology and its inseparability from specific agricultural practices (Glover 2010; Gutierrez et al. 2015; Kranthi 2016; Flachs 2019a; Kranthi and Stone 2020).

Early studies largely based on pre-2008 data argued that Bt cotton technology led to higher effective yields and even "strongly outperformed" its conventional equivalent (Kathage and Qaim 2012; p. 1; Naik et al. 2005; Sadashivappa and Qaim 2009; Subramanian and Qaim 2009; Choudhary and Gaur 2015). Consequently, Bt cotton is claimed to have contributed to "positive economic and social development", as farmer profits are reported to have increased accordingly (Kathage and Qaim 2012, p. 1; Sadashivappa and Qaim 2009). As this was believed to have led to higher living standards for adopting HHs, Bt cotton was by some denoted as a pro-poor technology (Sadashivappa and Qaim 2009; Kathage and Qaim 2012; Yadav et al. 2018). Later studies, however, found lower contributions of the technology to the positive effects in recent cotton production figures and instead attributed these positive overall effects to a multitude of agrarian factors, most prominently the use of hybrid seed, the expansion of irrigation facilities,

\footnotetext{
${ }^{6}$ As outlined by Glover (2007, p. 123), this alliance was "a convenient mechanism to facilitate Monsanto's introduction of its transgenic traits to the Indian market", as a solitary market entry had previously failed in 1993.

7 The third herbicide-tolerant (HT) generation of Bt cotton technology (Bollgard III) is not (yet) commercialized in India. However, its unauthorized cultivation has recently sparked a major controversy among cotton farmers and authorities in the country (ISAAA 2017). The risk of resulting herbicide treadmills in this regard was indicated by Stone and Flachs (2017).
} 

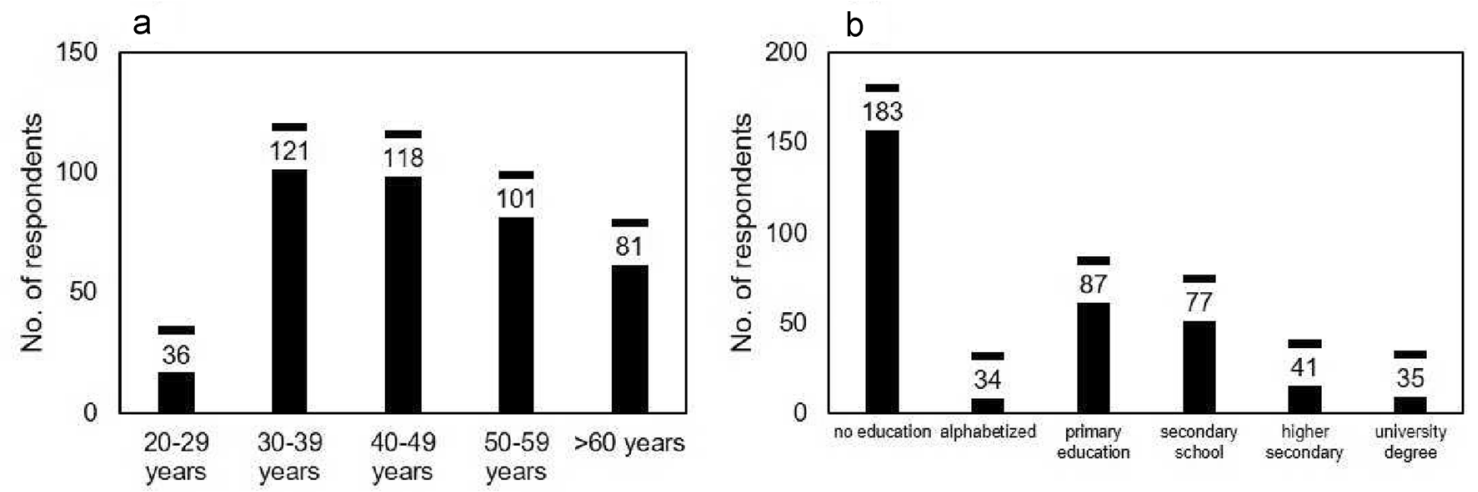

Fig. 2 a Age structure of the HH heads $(n=457)$; $\mathbf{b}$ highest education level of the HH heads $(n=457)$

and increases in fertilizer application (Glover 2010; Stone 2011; Gutierrez et al. 2015; Kranthi 2016; Flachs 2019a; Kranthi and Stone 2020). Accordingly, they question the proclaimed successes of Bt cotton in rural poverty reduction (Glover 2010) and report negative social (erosion of farmers' knowledge) (Stone 2007; Flachs 2019a) and ecological side effects (outbreaks of secondary pests, upcoming resistance to the target pest) (Kranthi 2015, 2016; Gutierrez 2018; Flachs 2019a; Tabashnik and Carrière 2019; Kranthi and Stone 2020).

Recently, the debate was reignited after unusually high levels of PBW infestation were reported for the states of Gujarat, Madhya Pradesh, Maharashtra, Karnataka, Andhra Pradesh, and Telangana in the kharif $^{8}$ season of 2015 and after (Mohan 2017; Fand et al. 2019). Progressive increases in the survival rate of PBW larvae within cultivated Bollgard II hybrids have been reported; these increases are viewed as indicators that larvae have developed resistance against the endotoxins produced in cotton plants (Mohan 2017; Naik et al. 2018; Fand et al. 2019). Fand et al. (2019, p. 313) estimated related yield losses of up to $30 \%$ per farming $\mathrm{HH}$ for the state of Maharashtra. As these studies have helped to clarify, after its hiatus lasting almost two decades, the PBW has returned to the cotton belt of central and southern India (Kranthi 2015; Mohan and Sadananda 2019; Tabashnik and Carrière 2019)—a development that fundamentally changes the situation for Bt cotton-farming HHs in this area. Against this backdrop, an analysis of the newly evolved vulnerabilities resulting from pests returning to Bt cotton farms is highly relevant.

\footnotetext{
${ }^{8}$ In Telangana, depending on the species planted, crops are grown in two different seasons. The season of kharif (monsoon season), in which cotton cultivation takes place, refers to the autumn season and begins in June. The season of rabi refers to the winter and usually begins after the kharif crops are harvested.
}

\section{PBW pest infestations and their impacts on cotton-farming HHs in Telangana}

\section{Background information on the studied cotton-farming $\mathrm{HHs}$}

The basic figures of our study sample are as follows. Of the 457 interviewed HHs, 446 were led by a male and 11 by a female. Figure 2 shows the age structure of the HH heads and their education levels. The interviewed HHs had an average size of 4.3 people, of which 2.0 people contributed to $\mathrm{HH}$ income. In addition, 2.2 generations on average were accommodated in the HHs.

The mean farmland size of the interviewed HHs amounted to 5.5 acres, with a minimum of 0.5 acres and a maximum of 50 acres $(n=456)$. Of these, 4.1 acres on average were owned, which corresponds to $83 \%$ of the total cultivated farmland, with a minimum of zero and a maximum of $100 \%$ owned farmland and slight differences at the district level (Adilabad, 74\%; Nalgonda, 81\%; Warangal, 88\%) $(\mathrm{n}=456)$. Cotton cultivation occurred on 4.0 acres on average $(73 \%)$, with noticeable differences at the district level (Warangal, 56\%; Adilabad, 77\%; Nalgonda, 89\%) $(\mathrm{n}=453)$ (Fig. 3).

The vast majority of interviewed HHs (86\%) had grown Bt cotton for an average of 8 years per HH. The remaining interviewees (14\%) answered that they were unaware of whether they were growing Bt cotton, with the exception of one $\mathrm{HH}$ that reported growing non-Bt cotton. Examples of seed brands used ranged from Nuziveedu (e.g., Bhakti, Mallika) and Rasi (659) to Aditya (Moksha). One per cent of the interviewed HHs stated that they were growing illegal, HT Bollgard III cotton. 
a

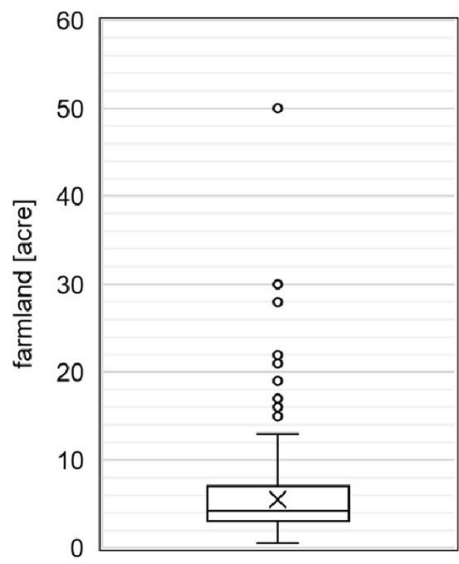

b

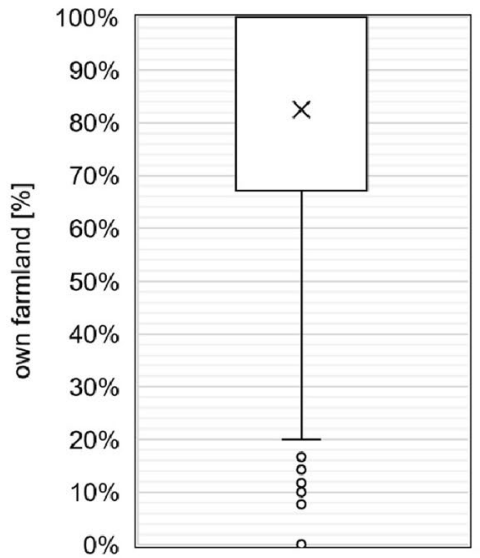

C

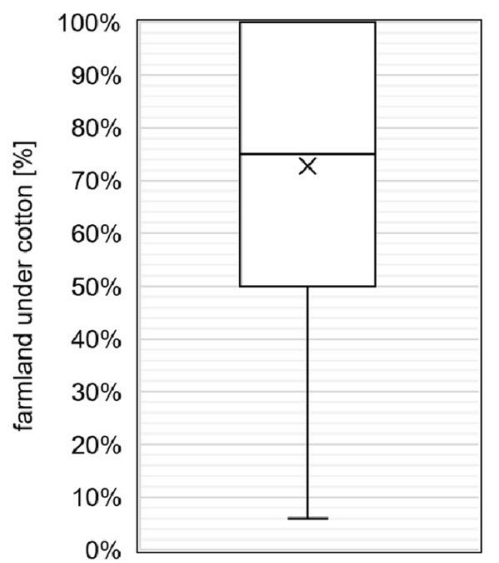

Fig. 3 a Overall farmland $(n=456)$; $\mathbf{b}$ owned farmland $(n=456)$; farmland under cotton cultivation $(n=453)$

\section{Exposure of cotton-farming HHs to PBW pest infestations}

Our results confirm that PBWs have returned to cotton fields in Telangana, as $80 \%$ of all interviewed HHs affirmed having faced PBW pest infestations in their fields during the past 5 years $(n=457)$. Of these, $96 \%$ reported the first appearance of this pest within the past 5 years, as our interviewees reported a total of 354 first cases of PBW infestation from 2014 to $2018(n=367)$. The largest share of PBW occurrences was found in Adilabad, at $84 \%$, and the smallest was found in Nalgonda, at $77 \%$ ( $81 \%$ in Warangal). The low degree of variation in the number of HHs experiencing PBW infestations indicates little geographical variability in PBW infestations in the three districts. As shown in Fig. 4, the number of first cases of PBW pest infestation increased drastically from 2014 (eight first cases), peaking in 2017 with a total of 150 first cases, after which the number decreased in 2018 to a total of 68 new cases.

On average, PBW pest infestation occurred within 1.95 years per $\mathrm{HH}$ in the period between 2014 and 2019; Adilabad (2.07) and Warangal (2.06) showed the highest frequencies, while in Nalgonda, lower numbers of infestations were reported on average (1.77). With a mean impact of 1.32 , where 0 represents no impact and 2 equals a severe impact, these recent pest infestations were evaluated as having moderate negative impacts ranging from 1.29 in Nalgonda and 1.30 in Warangal to 1.42 in Adilabad. ${ }^{9}$ The

\footnotetext{
9 The grading was based on the perceptions of the farmers surveyed. The Likert scale values (low, moderate, severe) therefore represent relational values, where low impacts could represent the observation of a problem without further consequences, moderate impacts could represent noticeable losses in yields, and severe impacts could be interpreted as total yield loss, e.g., through the practice of slashing and burning entire harvests (Najork et al. 2021).
}

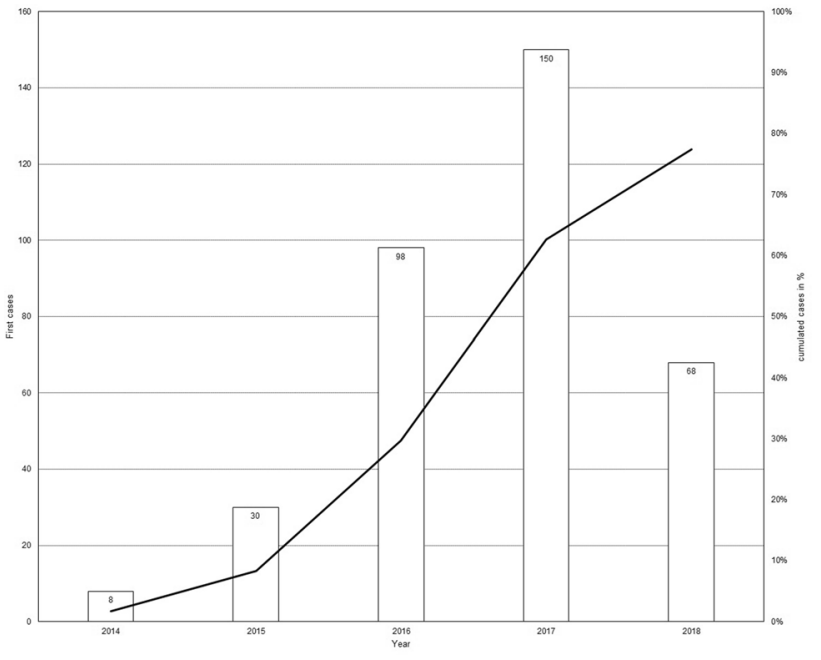

Fig. 4 Temporal distribution of the first reported cases of PBWs (line graph, $n=457$; bar graph, $n=367$ )

interviewed HHs perceived PBW infestation as the most severe agricultural problem among all other relevant problems related to Bt cotton production (Fig. 5). The lower frequency value may be explained by the recency of the pest's reemergence as an agricultural problem. Our findings therefore suggest that PBW infestation is classified as a lowfrequency/high-impact risk (Keck et al. 2012). As shown in Fig. 5, all other threats were perceived as less severe and, thus, fell within the range of low-frequency/low-impact risks (for example, spoiled seed, untimely rains, insufficient available labour), high-frequency/low-impact risks (sucking pests), or high-frequency/high-impact risks (weeds). 
Fig. 5 Frequency and severity of agricultural threats in the past 5 years (average Likert scale for severity from 0 [no impact] to 2 [severe impact]; for frequency, from 0 [no occurrence] to 5 [occurred five times in 5 years] $[\mathrm{n}=448-454$, variation according to the frequency and severity of individual threat parameters])

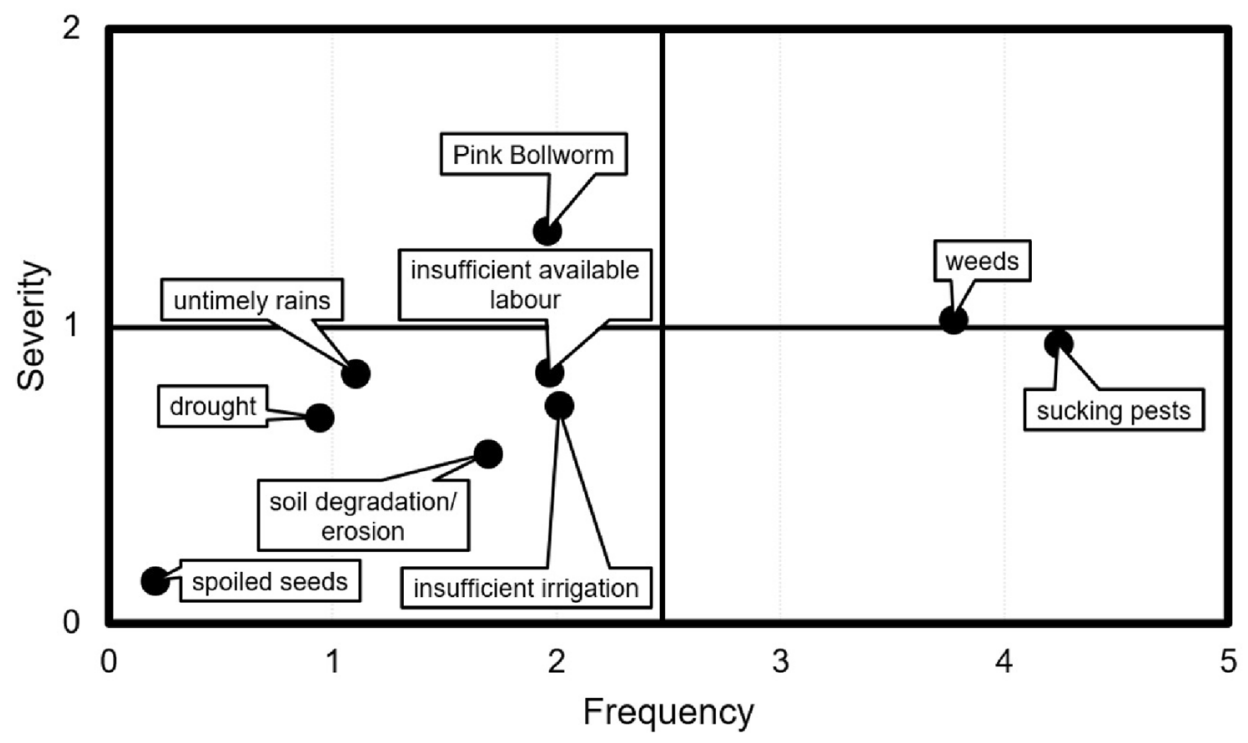

Fig. 6 Acres, yield, income, pesticide usage, and fertilizer applications in 2014-2018 compared to those in the previous year (average Likert scale from -2 [strong decrease] to +2 [strong increase]) $(\mathrm{n}=341-356$, variation according to parameter and year)

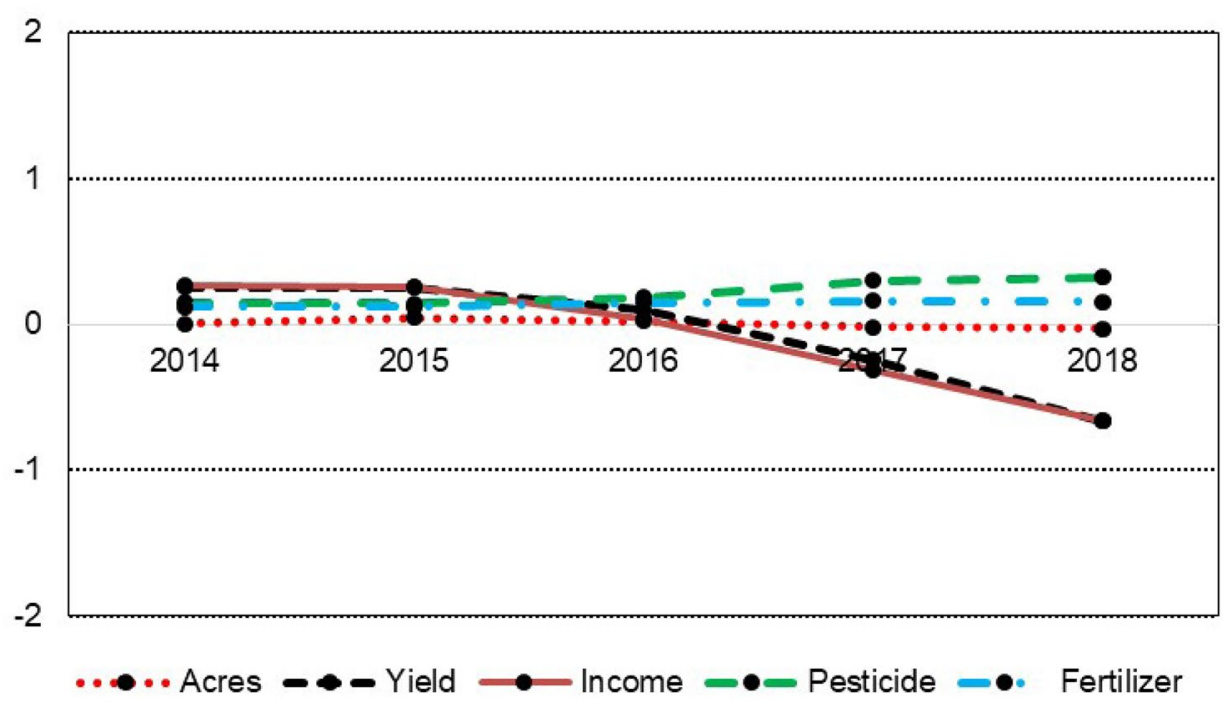

\section{Susceptibility of cotton-farming HHs to PBW pest infestations}

In accordance with the recorded first cases of PBW pest infestation in our sample, farmers' cotton yields and related incomes showed a clear negative trend from 2015 onwards. By using a range from a 'strong increase' (2) to a 'strong decrease' $(-2)$ in yields and income compared to those in the previous year, Fig. 5 shows a slight increase in yields and cotton-related income for 2014 (0.26) and 2015 (0.25), whereas it depicts a continuously declining trend from 2016 (yield, 0.01; income, 0.03) onwards (yield in 2017, - 0.24; income in 2017, - 0.31; yield and income in 2018, - 0.66).

As shown in Fig. 6, the usage of pesticides and fertilizers increased slightly from 2014 to 2018 (pesticides: 0.15 in 2014-2015, 0.32 in 2018. Fertilizers: 0.12 in 2014-2015,
0.16 in $2017,0.15$ in 2018). Notably, HHs owning less than $50 \%$ of their farmland disproportionately increased their pesticide usage, while those owning more than $50 \%$ of their farmland decreased in the same manner-a trend that continuously intensified between 2016 and 2018, as increasing correlation coefficients showed (2016: $\rho=-0.127$, $p=0.035, n=376 ; 2017: \rho=-0.159, p=0.005, n=386$; 2018: $\rho=-0.164, p=0.004, n=388)$. The cotton-related acreage, in contrast, remained almost the same $(0.01$ in 2014 ; -0.03 in 2018).

\section{Coping mechanisms of cotton-farming HHs in response to $\mathrm{PBW}$ pest infestations}

As a direct response to the return of PBW pest infestations, $11 \%(n=457)$ of the interviewed HHs had to take loans 

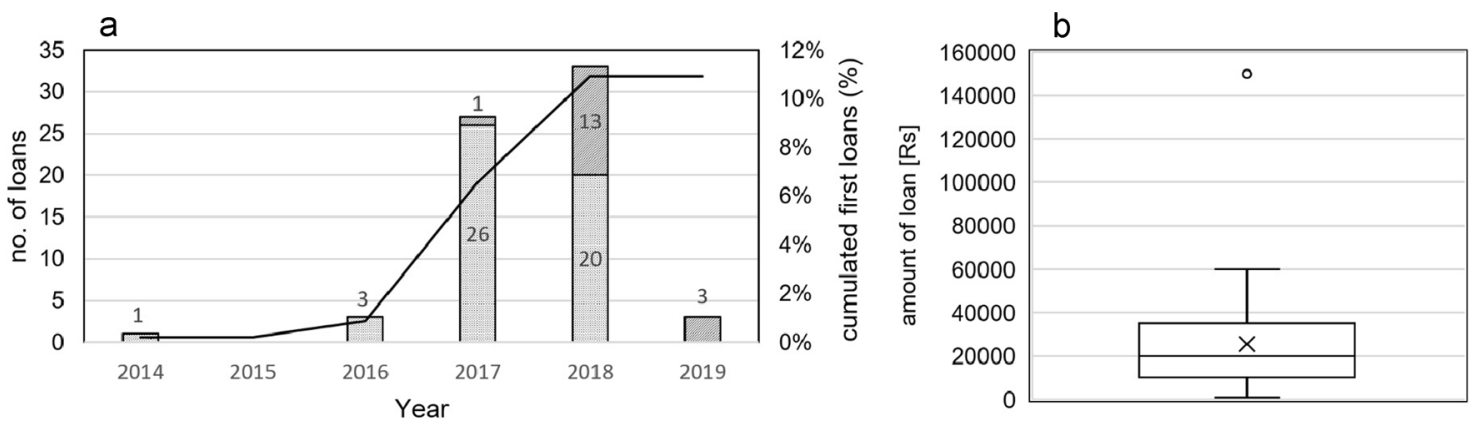

$\square$ first loans $\square$ repeated loans $\quad$ cumulated first loans (\%)

Fig. 7 a Temporal distribution of loans directly related to PBW infestation (line graph, $\mathrm{n}=457$; bar graph, $\mathrm{n}=67$ ); $\mathbf{b}$ distribution values of loans taken from 2014-2019 $(n=57)$

during the previous 5 years. It is worth noting that $24 \%$ of the respondents did not answer this question, which may be associated with its high degree of sensitivity. In terms of district comparisons, Nalgonda shows disproportionately high values; $14 \%$ of the interviewed cotton farmers had to take loans related to the reoccurrence of PBW pests, whereas in Adilabad and Warangal, these numbers were slightly lower (10\% and $9 \%$, respectively). At the village level, the respective figures vary from $0 \%$ (village 10 in Warangal) to $31 \%$ (village 15 in Nalgonda).

The amount of loans ranged from 1000 Rs to 60,000 Rs, with a clear outlier of 150,000 Rs and a clear distribution, as shown in Fig. 7. To access these loans, in $83 \%$ of the cases, our interviewees referred to informal sources, such as landlords or commission agents, while only $17 \%$ answered that they had obtained loans from the formal system $(n=59)$. Thirty\% of those HHs who took a loan once $(n=50)$ had to take loans at least once again and up to four times. More than two-thirds (68\%) of the HHs that took a loan related to the target pest were still indebted $(n=50)$. Notably, the share of still-indebted farmers in Warangal was noticeably lower (47\%) than that in the other two districts (Adilabad, 80\%; Nalgonda, 78\%).

Figure 7 a shows that the total number of loans taken has increased throughout the past 5 years, increasing rapidly in 2017 (27 cases), peaking in 2018 (33 cases), and decreasing again in 2019 (three cases), resulting in a total of 67 cases $(n=50)$. This gradient fits well with the counted cases of PBW pest infestations among our studied farming $\mathrm{HHs}$, although the procurement of loans lags 1 year behind. Furthermore, we found that the number of repeated loans increased noticeably (Fig. 7a). Again, this surge peaked with a time lag of yet another year, indicating farmers' increasing difficulties in coping with the PBW infestation shock.

A rarely pursued coping strategy involves asking seed companies for compensation. Only 7\% $(n=274)$ of the interviewed HHs asked for compensation, and only $2 \%$ actually succeeded. Almost two-thirds (64\%) of the HHs that did not ask for compensation reasoned that there was no prospect of success and, thus, refrained from trying to obtain compensation. Nearly one-third of the respondents (31\%) answered that they were not interested in trying or were not aware of this possibility.

\section{Adaptive capacities of cotton-farming HHs in dealing with $\mathrm{PBW}$ pest infestations}

Our respondents changed their agricultural practices in response to the returned PBW pests. This change varied among the surveyed villages and was thus underlined by a strong correlation coefficient with $\mathrm{HH}$ villages of 0.306 $(\varphi)$, with a $p$ value of $0.006(\mathrm{n}=330)$. Moreover, this change was moderately correlated with the frequency $(\varphi=0.250$, $p=0.000)$ and severity $(\varphi=0.238, p=0.000)$ of PBW outbreaks $(\mathrm{n}=329)$. According to cross-tabulations, farmers avoid changing their production patterns with low frequency and perceived severity levels of PBW pest infestations, but they change their practices in response to more frequent PBW infestations and a higher perceived impact. As such, altered agricultural practices were mainly found in response to severe levels of perceived pest infestation impacts.

Overall, 33\% $(n=350)$ of all interviewed HHs altered their agricultural production patterns, of which $36 \%$ changed their seed type or brand, $35 \%$ increased their usage of pesticides, and 29\% reduced their cotton acreage. Additionally, $25 \%$ of the respondents $(n=372)$ reported growing a second crop during the following rabi season, which was usually maize (92\%). Correlations and cross-tabulations suggest a distinct sequence pattern of succession regarding these adaptive strategies contingent on the impact of PBW pest infestations; while interviewees tended to increase their usage of pesticides when there was a lower frequency (1-2) of PBW pest infestations, they more often reduced their acreage 
Fig. 8 Influence of PBW pest infestations on agricultural adaptation strategies

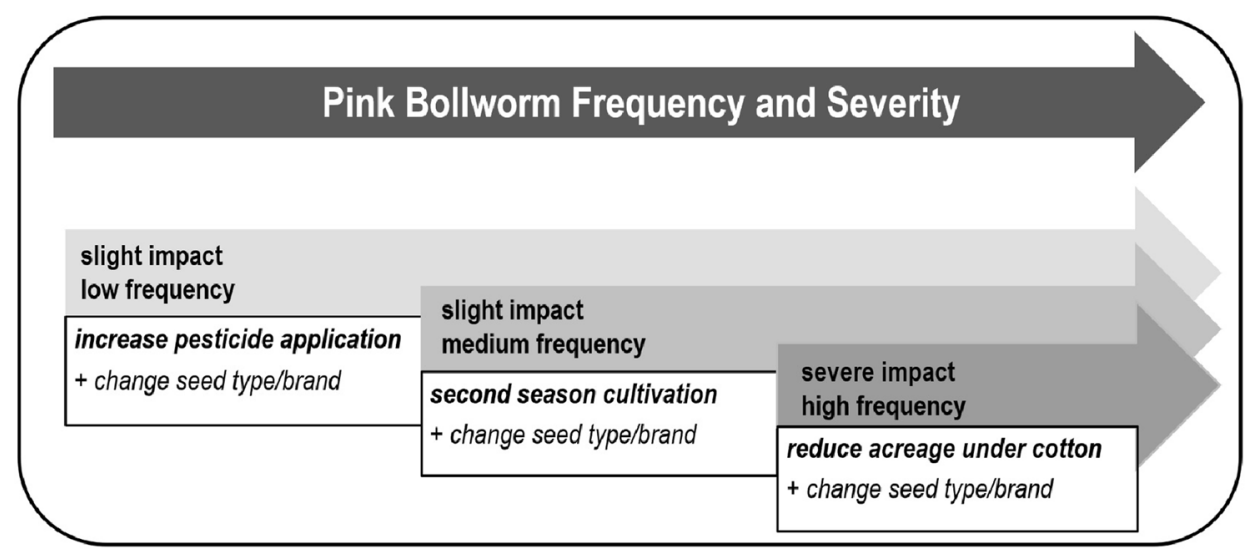

under cotton when there was a higher frequency (3-5) of PBW pest infestations (Fig. 8). Similarly, the interviewed HHs increased their application of pesticides when there was a slight perceived impact of PBW pest infestations but reverted to a reduction in acreage only when there was a severe perceived impact (Fig. 8). Second-season cropping was implemented when the perceived severity $(\varphi=0.226$, $p=0.000)$ and frequency $(\varphi=0.337, p=0.000)$ levels of PBW infestations $(n=371)$ were moderate. Changing seed type or brand, in contrast, was found to be adopted in addition to implementing the other strategies; however, these changes were not distinct adaptive strategies.

These findings indicate that respondents tended to avoid acreage reduction and that this strategy served as a last resort to address increasingly frequent and severe pest infestations. Moreover, both the perceived severity $(\varphi=0.291, p=0.000)$ and frequency $(\varphi=0.251, p=0.000)$ of PBW pest infestations showed a moderate correlation with the manner of change in the mentioned agricultural practices $(n=347)$. Altogether, farming HHs moved from employing strategies of agricultural intensification to those of agricultural diversification. The latter strategies therefore stand out as being particularly important regarding the development of resilience to PBW infestations.

Of our interviewees, $63 \%(n=457)$ responded that they grow other crops in addition to cotton, which included paddy $(44 \%)$, turmeric $(18 \%)$, maize $(14 \%)$, or pulse $(7 \%)$ crops $(\mathrm{n}=287)$. However, the cultivation of additional crops varied widely among the districts, from $28 \%$ in Nalgonda to $72 \%$ in Adilabad and $87 \%$ in Warangal. ${ }^{10}$ Moreover, the diversity

\footnotetext{
10 This geographical difference in regard to agrobiodiversity is striking, as other researchers have reported the cultivation of additional crops to be a common smallholder strategy (Flachs 2015; Flachs and Stone 2019; Kannuri and Jadhav 2018; Krishna et al. 2016). We suspect water to be the decisive factor here: first, we see water to be a limiting factor in regard to adaptive strategies of agricultural diversification (Evans and Giordano 2012; Gutierrez et al. 2015; Raizada et al. 2018; Kuchimanchi et al. 2019), and second, we found correlations between district and water availability, both of which are
}

of additionally cultivated crops differed among the three districts; while the largest share of crops aside from cotton consisted of paddy in Nalgonda and Adilabad (72\% and $60 \%$, respectively), additional crop production appeared to be more diversified in Warangal (34\% paddy, $26 \%$ turmeric, $22 \%$ maize $)(\mathrm{n}=287)$. These findings were also confirmed via correlation analysis, which showed a strong correlation between the cultivation of other crops and villages in different districts $(\varphi=0.545, p=0.000, n=457 ; \varphi=0.584$, $p=0.000, n=457$ ).

\section{Factors limiting the ability of cotton-farming HHs to adapt to PBW pest infestations}

Given that we found several significant correlations, the water availability factor needs to be considered a key factor in regard to farming HHs' adaptive capacities to deal with PBW pest infestations. Our findings show that, overall, HHs were significantly more prone to alter their production as long as drought or a lack of irrigation did not appear to be problematic, which were measured in terms of the frequency and perceived severity of the occurrence of these problems (drought frequency: $\varphi=0.236, p=0.000, n=346$; drought severity: $\varphi=0.231, p=0.000, n=345$; insufficient irrigation frequency: $\varphi=0.193, p=0.000, n=344$; insufficient irrigation severity: $\varphi=0.221, p=0.000, n=343$ ). Our cross-tabulation data indicate that a particular sequence of suitable adaptive strategies exists in regard to the influence of water availability (Fig. 9). As long as the problem of water scarcity is marginal (in terms of its frequency of incidence and perceived severity), HHs tend to reduce their acreage, grow a second crop during the following rabi season, or increase their usage of pesticides. In contrast, when the problem of

\section{Footnote 10 (continued)}

described below. A thorough discussion on this is, however, beyond the scope of this paper. 
Fig. 9 Influence of water scarcity on agricultural adaptation strategies

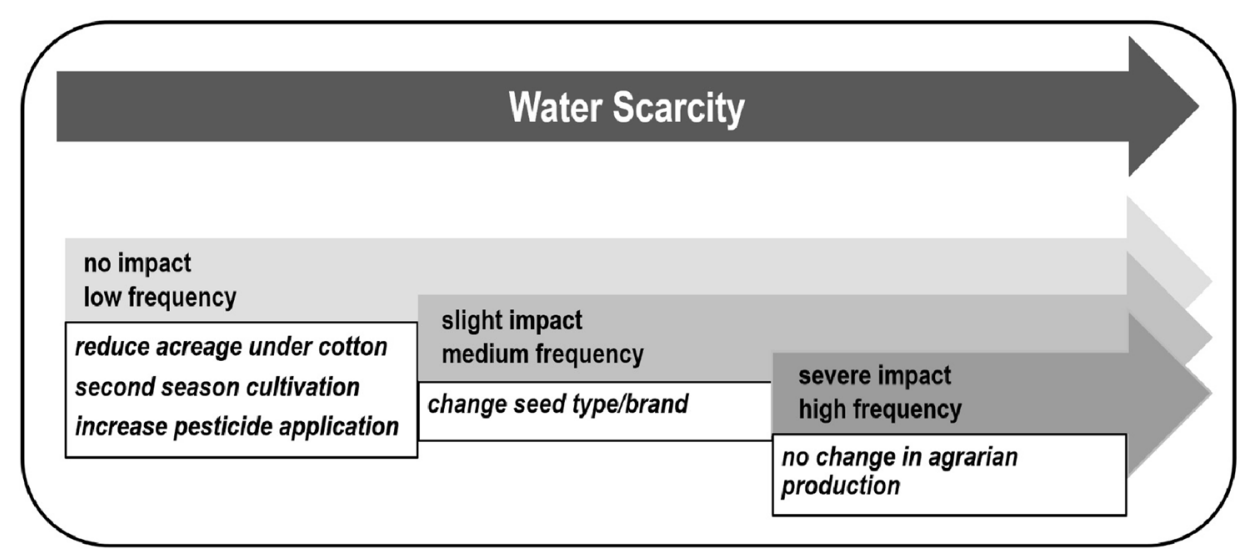

water scarcity is more frequent and intense, HHs tend to change their seed types or brands. However, when the problem of water scarcity is omnipresent and perceived as being highly severe, HHs tend not to alter their production at all. In particular, the diversification strategy was influenced by the water availability factor. For example, we found significant correlations of second-season cropping and insufficient access to irrigation facilities (frequency: $\varphi=0.427$, $p=0.000, \mathrm{n}=366$; severity: $\varphi=0.410, p=0.000, \mathrm{n}=365$ ).

Regarding the limiting factor of access to irrigation, we found correlations for perceived severity with respect to district $(\varphi=0.183, p=0.001)$ and village $(\varphi=0.307, p=0.000)$ $(n=448)$. This suggests that the adaptive strategies of our interviewed farmers are influenced by heterogeneous localities and climates, as these are crucial factors in determining the likelihood of drought occurrence and farmers' access to irrigation facilities. However, the much higher correlation value at the lower-scale village level suggests that infrastructural asset features determine farmers' access to water even more.

\section{Discussion}

We have shown how the return of the PBW has altered the vulnerability of cotton-farming HHs in the state of Telangana. In the following text, we contextualize these vulnerability-related findings by highlighting their political-economic implications. We argue that (1) Bt cotton contains an inherent sociobiological obsolescence, which has resulted in technological failure in the sense that protection against PBW infestations can no longer be guaranteed; (2) this technological failure has altered farming HHs' vulnerability context depending on their economic situation, resulting in the dispossession of resource-poor farmers and the possible appropriation of their assets by other actors; and (3) this dispossession ultimately helps the current neoliberal agrifood regime in India become hegemonic as it prepares the ground for achieving "local acquiescence" (Brown 2019, p. 193) among those who are better off.

\section{Sociobiological obsolescence of Bt cotton}

Our study provides evidence for the reemergence of PBW pest infestations in the districts of Adilabad, Warangal, and Nalgonda. As the vast majority of our interviewees used Bollgard II seeds and as many as $80 \%$ of them affirmed having recently faced PBW infestations, we substantiate other scholars' findings of evolved biological resistance to the target pest against the currently used second-generation $\mathrm{Bt}$ cotton seed (Dhurua and Gujar 2011; Mohan 2017; Naik et al. 2018; Fand et al. 2019; Mohan and Sadananda 2019; Tabashnik and Carrière 2019). We further found that the target pest's return has implications on a practical level, as interviewed Bt cotton-farming HHs have incurred severe yield and income losses (Naik et al. 2018; Fand et al. 2019; Tabashnik and Carrière 2019). Following the resistance of the PBW to the first generation of Bt seeds in 2009 (Haribabu 2014; Mohan 2017; Naik et al. 2018), our findings suggest that the current variant has also failed.

Following Haribabu (2014), we argue that this breakdown of two consecutive generations of Bt cotton shows that a general obsolescence is inherent in the current form of $\mathrm{Bt}$ technology. We propose the term sociobiological obsolescence to describe this phenomenon. While the technology is socially constructed and embedded, as it is produced in labs and implemented by farmers and its development underlies public political debates, it simultaneously results from biological qualities and is integrated into biological linkages. Due to the biologics of the struggle between pest and host species, Bt technology automatically increases the evolutionary pressure on the target pest, which continually develops new resistance. ${ }^{11} \mathrm{We}$ argue that this dynamic eventually

\footnotetext{
11 This interdependent and alternating process is described by the red queen hypothesis in the field of evolutionary biology. It assumes
} 
Fig. 10 Model of sociobiological obsolescence of Bt cotton technology in relation to profits

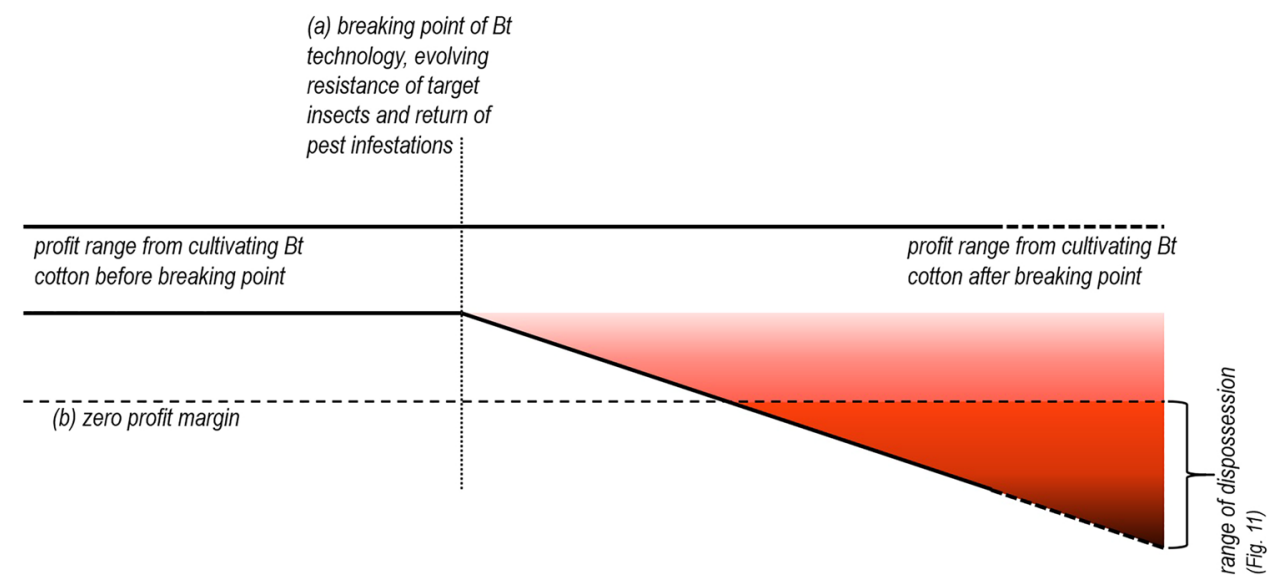

results in an arms race between farmers equipped with $\mathrm{Bt}$ cotton technology and its inherent toxins and target pests, in this case the PBW, endowed with the relevant resistance traits that have evolved as a result of the increased evolutionary pressure. From this, we derive an inherent obsolescence of $\mathrm{Bt}$ technology resulting from its embeddedness in both social and biological factors.

In this paper, the term sociobiological obsolescence therefore describes the predetermined breaking point that is inherent in Bt technology and has been from the very beginning due to its social and biological embeddedness. We emphasize that due to its biological contingency, this obsolescence is not to be grasped as deliberately initiated and, thus, contrasts with the 'planned' obsolescence practices common in the manufacturing industry. However, we nevertheless see that the outcome of the obsolescence shows clear parallels; i.e., a predetermined breaking point is inherent to the Bt product itself through the technology's social and biological embeddedness in accordance with evolutionary biologics (Fig. 10). This, in turn, increases the pressure on consumers to buy ever-new products-and, hence, the risk of entering a technology treadmill — to maintain the status quo, in this case farmers having to buy new generations of Bt technology (cf. Stone and Flachs 2017). We thus argue that the technology design of Bt cotton was flawed from the start, as it had ab initio been dependent on biological developments.

In addition to early warnings from entomologists and pest management specialists, even seed producers anticipated their products' limited life cycle and suggested that farmers plant non-Bt cotton refuge crops (Kranthi et al. 2017; Mohan 2018, 2020; Tabashnik et al. 2021). This measure, however, did not aim to entirely avoid the breaking point but only to

\footnotetext{
Footnote 11 (continued)
}

that parasites become specialized in regard to certain host species and thereby reduce their fitness (cf. Clay and Kover 1996). delay it (Kranthi et al. 2017; Mohan 2018, 2020; Tabashnik et al. 2021). Bt cotton thus never provided benefits that were "sustainable over time", as proclaimed early on by agroeconomists (Sadashivappa and Qaim 2009, p. 172; Krishna and Qaim 2012).

Similar to the corporate strategy of obsolescence, the breaking point of $\mathrm{Bt}$ technology has implications for seed producers and adopters alike. Due to its limited life cycle, Bt technology involves a risk for farmers such that they become trapped on a technological treadmill, which causes them to rely on ever-new generations of Bt cotton seeds in response to ever-new resistant pests, with corresponding profits gained by the seed industry (Stone and Flachs 2017). The almost exclusive reliance of Bt cotton in India on hybrid seeds reinforces these effects (Herring 2007; Ramasundaram et al. 2011; Gutierrez et al. 2015; Stone and Flachs 2017; Kranthi and Stone 2020).

By exposing the sociobiological obsolescence inherent to Bt technology, we confirm the claim of Taylor (2018) and Nightingale et al. (2020) that technology always needs to be assessed in practice (cf. Glover 2011). The case of Bt cotton in India is exactly one of the "techno-managerialist solutions" that policy makers, planners and the industry still favour (Nightingale et al. 2020, p. 345). These 'solutions', however, remain bound to an imaginary reductionist technological fix that has little to do with the experiences of people and the vibrant ecological reality at local levels. As our case shows, the study of technologies such as Bt cotton is less about the effects of autarkic artefacts but more about the sociobiological dynamics that artefacts spark in society and ecology. Against this backdrop, we view sociobiological obsolescence as a promising notion for the assessment and evaluation of future biotechnologies that are currently advertised to tackle the calamities associated with global environmental change. 


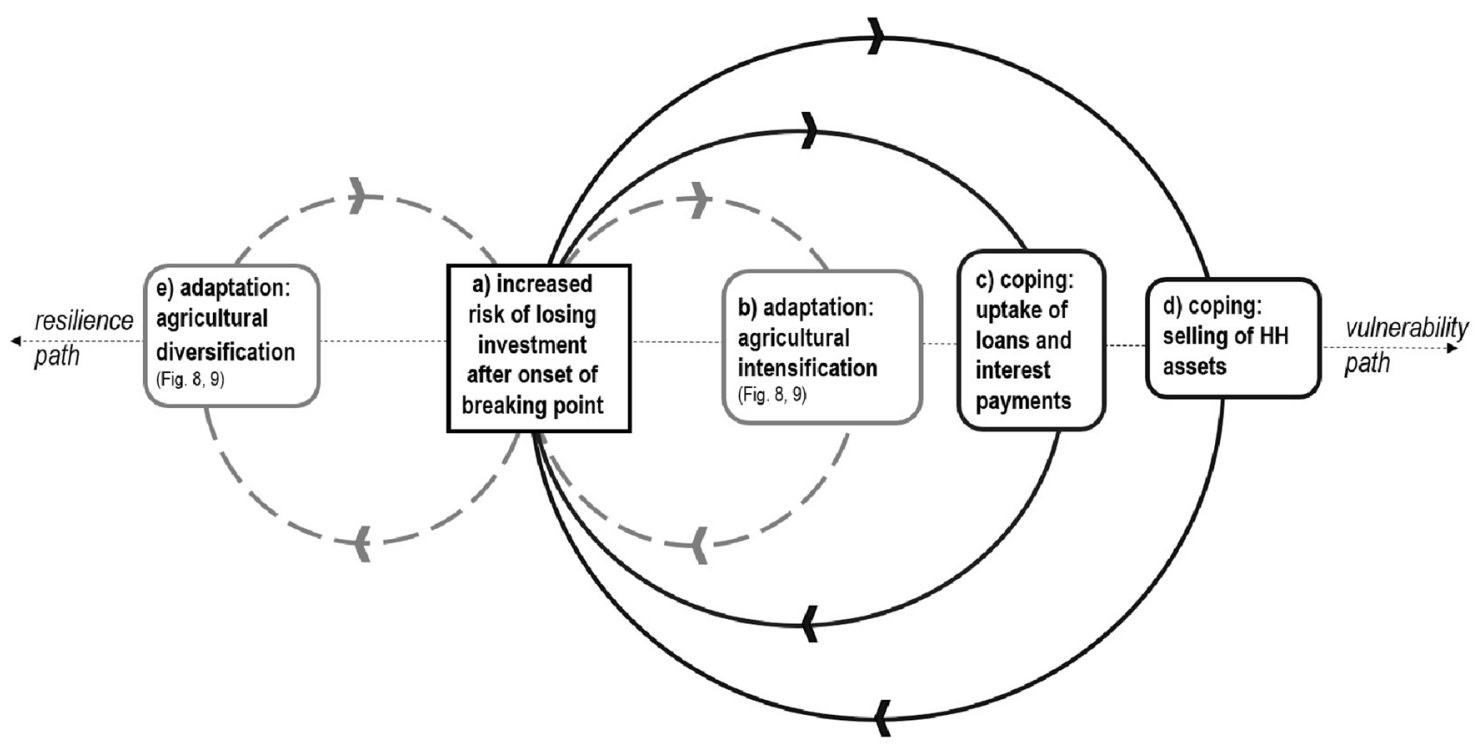

Fig. 11 Coping and adaptation strategies of farming HHs and the resultant paths of vulnerability or resilience

\section{Dispossession and appropriation}

Our findings further show that the sociobiological obsolescence of the current $\mathrm{Bt}$ cotton generation has altered the vulnerability of farming HHs. However, significant differences were found among the interviewed farmers in terms of their economic assets, as resource-poor farmers were especially hit hard by the return of the PBW. We argue that the increased vulnerability of disadvantaged farmers reflects a process of dispossession, which provides economically advantaged actors with opportunities to appropriate $\mathrm{HH}$ assets, thus reproducing the existing structures of the emerging neoliberal agri-food regime.

Gutierrez et al. (2015) found that the cultivation of Bt cotton increases the vulnerability of farmers in rainfed areas and argued that this originates from the combination of increased seed costs and continued insecticide costs with low and highly variable yields (Ramasundaram et al. 2007; Glover 2010; Kumar 2015; Matthan 2021). According to Gutierrez et al. (2015) and Gutierrez (2018), the cultivation of Bt cotton involves an increased risk of farmers becoming bankrupt and becoming burdened with debt (Vasavi 2012, 2020; Najork et al. 2021). While our data confirm the findings of these studies (Gutierrez et al. 2015; Gutierrez 2018), our findings also suggest a need to further differentiate among groups of $\mathrm{Bt}$ cotton farmers based on their economic situation. This can be shown when loans are considered. In our study, the vast majority of loan recipients had to rely on informal sources, such as landlords or commission agents, due to the restricted access of the otherwise preferred formal banking system to land- or gold-owning HHs (Pal 2002; Altenbuchner et al. 2018; Najork et al. 2021). As these informal sources usually have exorbitant interest rates-Gutierrez et al. (2015, p. 10) describe "usury costs" of 5-10\% per month-they involve the danger of farmers becoming trapped in a debt cycle (Vasavi 2014, 2020; Gutierrez 2018; Ramprasad 2019; Najork et al. 2021). Our findings confirm that after having lost their investments in seed, fertilizer, and pesticides due to low or lost yields, some of our interviewed farmers had to repeatedly procure loans, and almost one-third of the already indebted HHs had to take additional loans in subsequent seasons. We therefore agree with Vasavi (2014, p. 33), who reported that "debt and indebtedness generate entrapments".

Moreover, we argue that the $\mathrm{HH}$ strategies follow either a 'resilience' or a 'vulnerability path' (Fig. 11) in response to the loss of investment after the breaking point (a). On the vulnerability path, this loss can lead to the uptake of loans and the payment of interest (c). If farmers become entrapped in this way and cannot pay back their debts, they are forced to sell their most valuable $\mathrm{HH}$ assets, such as gold, equipment, or land (d) (Najork et al. 2021). In summary, these involuntary reactions of farmers to address the Bt technological failure in turn increase the vulnerability of farmers and increase their risk of being faced with a crisis.

As a way to counteract this treadmill effect, our results indicate a resilience path taken by $\mathrm{HHs}$ with diversified production (Figs. 8, 9). This adaptation strategy (e), however, is only available to $\mathrm{HHs}$ that have the necessary resources. Economically weaker farming HHs were found to be unable to follow this pattern and were left with no alternative but to adhere to intensification practices (b). We found that one potential cause of this was related to the lack of availability and lack of access to sufficient water resources. Gutierrez 
et al. (2015) emphasized the differences between irrigated and rainfed Bt cotton areas in India and found that farmers in rainfed areas (central and southern India) face higher risks than those in irrigated areas (northern India). With our study, we can show in detail how this plays out in the current situation. As the capabilities of resource-poor farmers to afford adequate irrigation facilities are limited, these farmers are left with no alternative but to apply an increasing amount of pesticides when faced with PBW infestation. This form of agrarian intensification increases their input costs and leaves farmers at an increased risk of losing their investments when yields are not as expected. Thus, the constraints to agricultural diversification faced by resource-poor households are not caused by the increasingly obsolete seed cycles as such. However, the obsolescence described above exacerbates their production constraints by depriving them of further monetary resources that could contribute to more diversified agricultural production (e.g., through the installation of irrigation facilities). Hence, obsolescence-induced dispossession widens the gap between resource-poor and resource-rich HHs, and consequently, resource-poor HHs are further disadvantaged in terms of their adaptive capacities in response to the dispossession caused by sociobiological obsolescence.

Farming HH coping strategies (b) and (c) not only produce losers but also winners. As such, there is a counterpart to the story presented above that should not be neglected. Here, our findings are in accordance with those of Jakobsen (2018b, p. 15), who argues that "there are still accumulating classes", and with those of Lerche (2013, p. 400), who found that there has been no "general pauperization of all agrarian classes" and that "accumulation is disproportionately concentrated in the hands of the best-off groups in the best-off states" (Lerche 2014, p. 51). In our case, the winners are money lenders, often businesspeople, landlords, or large-scale farmers, who earn money from HHs in need by granting them loans and profiting from the associated interest and compound interest (Najork et al. 2021). If farming HHs have to sell their jewellery, the same group of people make gains. Finally, if farmers become unable to repay their debt and interest, the very mechanism described by Harvey (2005) as accumulation by dispossession gains traction; i.e., the farming HHs' crisis created by the sociobiological obsolescence of $\mathrm{Bt}$ cotton and intensified by their limited capabilities to cope forces farmers to sell their land-often under value, since the need for financial resources predominates. This freed capital can be easily seized by local elites and those who are better off, thus improving their personal economic situation while contributing to the further increase in farmland-related capital in the hands of a few. Our deductions, thus, highlight that for an analysis of neoliberal agrifood regimes, it is essential to consider perspectives of class and hegemony, as accumulation cycles and class dynamics are coproduced and "class forces in society have been instrumental in consolidating capitalist hegemony in India's integral state" (Jakobsen 2018b, p. 4; Aga 2019). In the following section, this is examined in more detail for our case of $\mathrm{Bt}$ cotton in the neoliberal Indian agri-food regime. ${ }^{12}$

\section{Local acquiescence to the neoliberal food regime}

In a recent paper, Brown (2019) argues that critical agrarian studies have overemphasized acts of resistance to agrifood regimes and thus sees the need to direct more attention towards the ways in which ordinary populations consent to the formation and stabilization of the emerging neoliberal regime in India (Brown 2019, p. 189). In his view, grand acts of resistance and outright rejection of agri-food regime principles are exceptions, whereas the more 'normal' scenario involves elite dominance and subaltern acceptance (Brown 2019). With the help of a Gramscian understanding of hegemony, Brown aims to highlight how the neoliberal agri-food regime becomes accepted and is conformed to by large parts of society, even if its functioning principles obviously work against them. Gramsci (1971, p. 180f) perceives a vital point in the ruling class to learn to guide the interests of subordinate groups such that they become harmonized with their own interests. As such, he perceives the need to win consent from the larger society with core agri-food regime principles, for which local mediation through a rural elite becomes key (Brown 2019, p. 192). Overall, this act of obtaining consent must be backed by a supportive state apparatus, which provides the necessary modes of governance so that the industry can continue to proceed in a selfserving accumulating regime.

Against this backdrop, we argue that money lenders, shop owners and landlords play-willingly or unwillingly - the role of local mediators. As they gain from the current biotechnology-driven cotton regime by means of earnings in the form of interest payments and the sale of arable land, they have an interest in prolonging and even strengthening this regime's very principles. In doing so, they reproduce the neoliberal agri-food regime in India, which eventually unabatedly contributes to increased accumulation for national and international seed corporations (Fig. 12). Our

\footnotetext{
12 With the term agri-food regime, we refer to food regime theory. Food regimes also include non-food crops, as they are concerned with the production and consumption of all agricultural products, such as agrofuels or cotton (Friedman and McMichael 1989; McMichael 2009). In fact, cotton plays a vital role in food regime theorization as the first food regime (1870-1930) described by Friedman and McMichael (1989) is considered to have established a breakthrough in international trade of industrial products, centred on colonial and national relations in which the fibre crop was traded. In an attempt to make this clear, we speak of agri-food regimes instead of food regimes.
} 


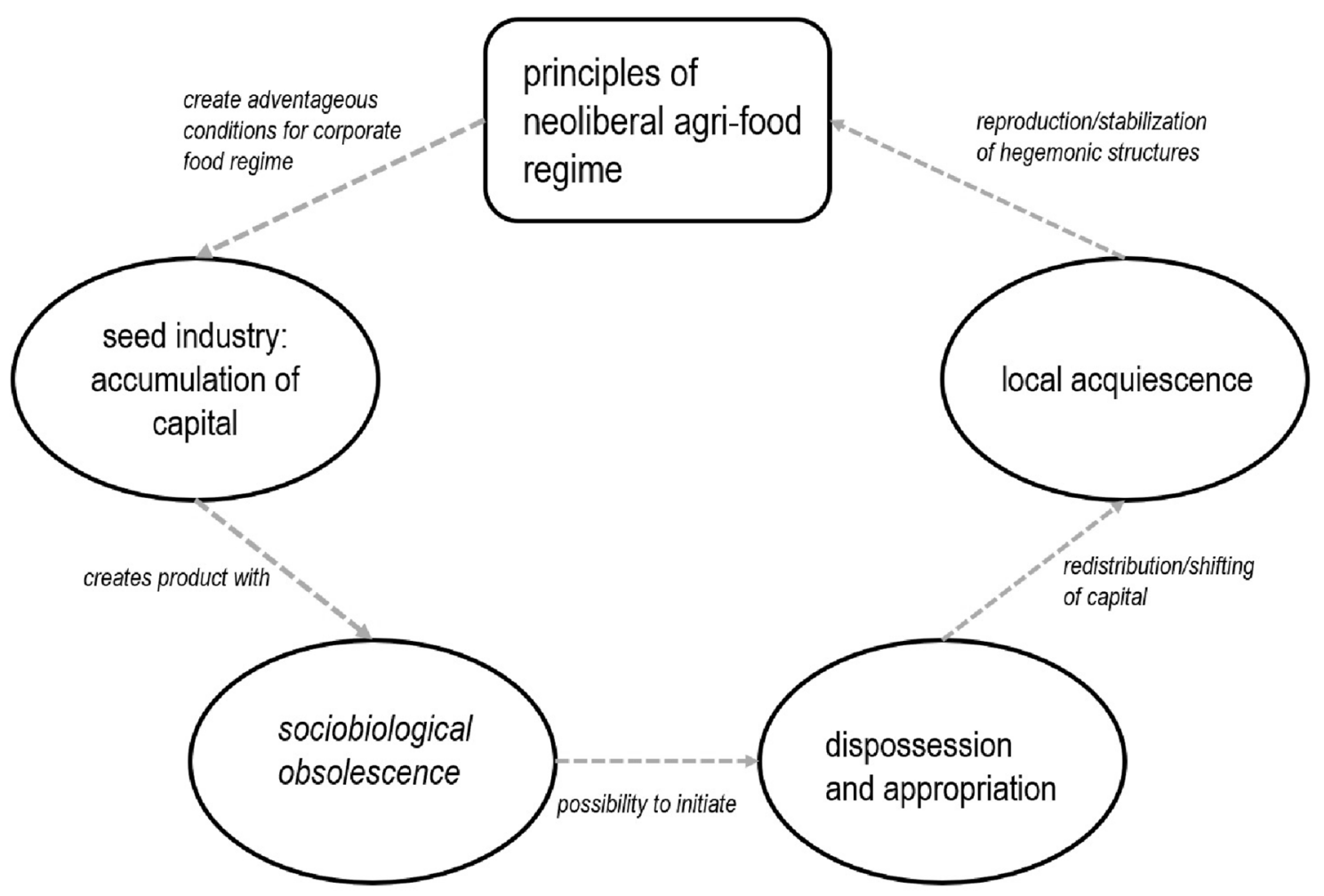

Fig. 12 Possible stabilization cycle of neoliberal agri-food regime principles

views are thus in line with those of Jakobsen (2018a), who criticizes the binary agribusiness-versus-smallholder perspective indicated in classic agri-food regime analysis perspectives (McMichael 2009). We see that established powers are favoured, and the underlying processes of accumulation in the current corporate agri-food regime are legitimized and, hence, stabilized through the local acceptance of rural beneficiaries (Jakobsen 2018a, b; Aga 2019; Brown 2019).

As a result, we emphasize the role of the classic rural elite, which comprises the actors mentioned above, as they play a key role in making corporate dominance in the Indian agrarian sector more socially acceptable (Jakobsen 2018a, b; Brown 2019). The very nature of the strategies, networks and mechanisms of how this works for our case in practice and how it is interrelated with the wider sociopolitical landscape at the local level remain to be studied in further detail in the future. However, at this point, we can suggest that $\mathrm{Bt}$ cotton, and with it other types of similar biotechnology forms, helps the neoliberal agri-food regime take a more mature hegemonic position in India-not due to seed industries that exert coercive means, but by a state-industry complex that provides ground for the rural elite to profit from the current regime, even though this is not the case for all farmers. The long-term consequences of this system are the continuing proletarianization of rural populations along with a further centralization of capital (for example, in the form of farmland and labour supply) in the hands of a few with each new sociobiological failure of Bt technology. We therefore emphasize that Glover (2010) has exposed the falsity of early-on claims classifying Bt cotton as a propoor technology (Kathage and Qaim 2012; Subramanian and Qaim 2010). With this contribution, we complement Glover's (2010) argument by providing final evidence on why Bt cotton was never a pro-poor technology to begin with.

\section{Conclusion}

This is the first study to provide insights into the political economy of the altered vulnerability context of farming $\mathrm{HHs}$ associated with the recent resistance of the PBW to secondgeneration Bt cotton (Bollgard II) in Telangana, India. Our study embeds vulnerability-related findings in a larger political-economic context by revealing a technology-driven form of dispossession caused by the sociobiological obsolescence of Bt cotton. Thus, as a neoliberal technology, Bt cotton constitutes one of many variegated mechanisms of neoliberalization that must be viewed as yet another form of capitalist appropriation and accumulation in the Global South.

We characterized Bt cotton as a neoliberal technology that includes an inherent sociobiological obsolescence that limits the technology's life cycle from the start. As such, 
Bt cotton has a predetermined breaking point that forces adopters to rely on ever-new generations of $\mathrm{Bt}$ seed and, thus, increases the risk of succumbing to 'technology treadmills'. Our findings suggested that this obsolescence results in vulnerability-related inequalities among farmers, depending on their economic status. We argued that resource-poor farmers are unable to follow a path to resilience and are led onto a vulnerability path that eventually results in dispossession. As a counterpart of this dispossession, we identified opportunities for appropriation by economically advantaged actors, such as money lenders, often businesspeople, landlords, or large-scale farmers, to gain from the current biotechnology-driven cotton regime by means of earnings in the form of interest payments and the sale of arable land. Thus, having an interest in maintaining the current principles of the prevalent neoliberal Indian agri-food regime, they reproduce this regime through local acceptance. In this way, by stabilizing the status quo of the underlying processes of the accumulation of capital by national and international seed corporations, they legitimize the current corporate agrifood regime in India. We therefore found the sociobiological obsolescence of $\mathrm{Bt}$ cotton to favour the established power relations that redirect capital from the bottom to the top at the expense of already financially disadvantaged HHs. This indicates striking parallels with the notion of accumulation by dispossession, as described by Harvey (2005).

Therefore, we conclude that Bt cotton has never been a pro-poor technology, as it continuously exacerbates present disparities with each crisis its failure initiates. Thus, we ask political authorities to counteract these incongruities by implementing protective mechanisms, such as obligatory compensation schemes to be complied with by seed companies. From our point of view, a long-term solution to ever-adapting target pest pressures cannot be found in yet another generation of $\mathrm{Bt}$ technology, as its inherent obsolescence causes recurring livelihood insecurities for Bt cottonfarming HHs.

Acknowledgements This paper has benefitted from the generous feedback of several anonymous reviewers. We are grateful for the time and thought these reviewers have contributed to our work, which significantly improved both, the clarity and stringency of our argumentation.

Funding Open Access funding enabled and organized by Projekt DEAL. This work was supported by the German Research Foundation (DFG) under Grant (KE1983/3-1)

Open Access This article is licensed under a Creative Commons Attribution 4.0 International License, which permits use, sharing, adaptation, distribution and reproduction in any medium or format, as long as you give appropriate credit to the original author(s) and the source, provide a link to the Creative Commons licence, and indicate if changes were made. The images or other third party material in this article are included in the article's Creative Commons licence, unless indicated otherwise in a credit line to the material. If material is not included in the article's Creative Commons licence and your intended use is not permitted by statutory regulation or exceeds the permitted use, you will need to obtain permission directly from the copyright holder. To view a copy of this licence, visit http://creativecommons.org/licenses/by/4.0/.

\section{References}

Adger, W.N. 2006. Vulnerability. Global Environmental Change 16 (3): 268-281.

Aga, A. 2019. The marketing of corporate agrichemicals in Western India: Theorizing graded informality. The Journal of Peasant Studies 46 (7): 1458-1476.

Agricultural Office Adilabad. 2014. Adilabad District Handbook 2014. Received in person as Excel file from the district office.

Agricultural Office Nalgonda. 2015. Hand Book of Statistics 2015. Received in person as Excel file from the district office.

Agricultural Office Warangal. 2014. Warangal District Handbook 2014. Received in person as Excel file from the district office.

Altenbuchner, C., S. Vogel, and M. Larcher. 2018. Social, economic and environmental impacts of organic cotton production on the livelihood of smallholder farmers in Odisha, India. Renewable Agriculture and Food Systems 33 (4): 373-385.

Birkmann, J. 2006. Measuring vulnerability to promote disaster-resilient societies: Conceptual framework and definitions. In Measuring vulnerability to natural hazards. Towards disaster resilient societies, ed. J. Birkmann. Tokyo: United Nations University Press.

Brenner, N., J. Peck, and N. Theodore. 2010. Variegated neoliberalization: Geographies, modalities, pathways. Global Networks 10 (2): $182-222$

Brown, T. 2019. When food regimes become hegemonic: Agrarian India through a Gramscian lens. Journal of Agrarian Change 20 (1): 188-206

Burnard, T.G. 2019. Planters, merchants, and slaves: Plantation societies in British America, 1650-1820. Chicago, Ill: University of Chicago Press.

Cáceres, D. 2015. Accumulation by dispossession and socio-environmental conflicts caused by the expansion of agribusiness in Argentina. Journal of Agrarian Change 15 (1): 116-147.

Carroll, M. 2017. The sticky materiality of neo-liberal neonatures: GMOs and the agrarian question. New Political Economy 22 (2): 203-218.

Castree, N. 2007. David Harvey: Marxism, capitalismand the geographical imagination. New Political Economy 12 (1): 97-115.

Choudhary, B., and K. Gaur. 2015. Biotech cotton in India, 2002 to 2014: Adoption, impact, progress \& future series of biotech crop profiles. ISAAA: Ithaca.

Clay, K., and P.X. Kover. 1996. The Red Queen hypothesis and plant/ pathogen interactions. Annual Review of Phytopathology 34 (1): $29-50$.

De Lange, N., and J. Nipper. 2018. Quantitative Methodik in der Geographie. Paderborn: Schöningh.

Dhurua, S., and G.T. Gujar. 2011. Field-evolved resistance to Bt toxin Cry1Ac in the pink bollworm, Pectinophora gossypiella (Saunders) (Lepidoptera: Gelechiidae), from India. Pest Management Science 67 (8): 898-903.

Di Muzio, T. 2007. The 'art' of colonisation: Capitalising sovereign power and the ongoing nature of primitive accumulation. New Political Economy 12 (4): 517-539.

Evans, A. E. V., and M. Giordano. 2012. Investing in Agricultural Water Management to Benefit Smallholder Farmers in Madhya Pradesh, India. International Water Management Institute, Working Paper 151. 
Fand, B.B., V.S. Nagrare, S.P. Gawande, D.T. Nagrale, B.V. Naikwadi, V. Deshmukh, N. Gokte-Narkhedkar, and V.N. Waghmare. 2019. Widespread infestation of pink bollworm, Pectinophora gossypiella (Saunders) (Lepidoptera: Gelechidae) on Bt cotton in Central India: A new threat and concerns for cotton production. Phytoparasitica 47 (3): 313-325.

Flachs, A. 2015. Persistent agrobiodiversity on genetically modified cotton farms in Telangana, India. Journal of Ethnobiology 35 (2): 406-426.

Flachs, A. 2019a. Cultivating knowledge. Biotechnology, sustainability, and the human cost of cotton capitalism in India. Tucson: The University of Arizona Press.

Flachs, A. 2019b. The Factish in the field. Science \& Technology Studies 32 (3): 26-43.

Flachs, A., and G.D. Stone. 2019. Farmer knowledge across the commodification spectrum: Rice, cotton, and vegetables in Telangana, India. Journal of Agrarian Change 19 (4): 614-634.

Folke, C., S.R. Carpenter, B. Walker, M. Scheffer, T. Chapin, and J. Rockström. 2010. Resilience thinking: Integrating resilience, adaptability and transformability. Ecology and Society. https:// doi.org/10.5751/ES-03610-150420.

Friedman, H., and P. McMichael. 1989. The rise and decline of national agricultures, 1870 to the present. Sociologia Ruralis 29 (2): 93-117.

Friedrich, J., K. Najork, M. Keck, and J. Zscheischler. 2022. Bioeconomic fiction between narrative dynamics and a fixed imaginary: Evidence from India and Germany. Sustainable Production and Consumption. https://doi.org/10.1016/j.spc.2021.12.026.

Füssel, H.-M. 2007. Vulnerability: A generally applicable conceptual framework for climate change research. Global Environmental Change 17 (2): 155-167.

Gaurav, S., and S. Mishra. 2012. To Bt or not to Bt? Risk and uncertainty considerations in technology assessment. In India's tryst with Bt cotton: Learning from the first decade, ed. L. Narayanan and P. Viswanathan. Indira Gandhi Institute of Development Research: Mumbai.

Glassman, J. 2006. Primitive accumulation, accumulation by dispossession, accumulation by 'extra economic' means. Progress in Human Geography 30 (5): 608-625.

Glover, D. 2007. The role of the private sector in modern biotechnology and rural development: The case of the Monsanto smallholder programme. Brighton: University of Sussex.

Glover, D. 2010. Is Bt cotton a pro-poor technology? A review and critique of the empirical record. Journal of Agrarian Change 10 (4): 482-509.

Glover, D. 2011. The system of rice intensification: Time for an empirical turn. NJAS - Wageningen Journal of Life Sciences 57: 217-224.

Government of India. 2011. 2011 Census Data. https://censusindia.gov. in/2011-common/censusdata2011.html. Accessed 27 May 2021.

Government of Telangana. 2017. Statistical Year Book 2017. Directorate of Economics and Statistics: Hyderabad.

Gramsci, A. 1971. Selections from the Prison Notebooks of Antonio Gramsci. In The modern prince \& other writings, ed. Q. Hoare and G.N. Smith. London: Lawrence and Wishart.

Gutierrez, A.P., L. Ponti, H.R. Herren, J. Baumgärtner, and P.E. Kenmore. 2015. Deconstructing Indian cotton: Weather, yields, and suicides. Environmental Sciences Europe 27 (1): 1-17.

Gutierrez, A.P. 2018. Hybrid Bt cotton: A stranglehold on subsistence farmers in India. Current Science 115 (12): 2206-2210.

Haribabu, E. 2014. Obsolescence of first generation GM cotton seed: Is it planned? Asian Biotechnology and Development Review 16 (3): 47-60.

Harvey, D. 2003. The fetish of technology: Causes and consequences. Macalester International 13 (7): 2-30.
Harvey, D. 2005. The new imperialism. Oxford: Oxford University Press.

Harvey, D. 2007. A brief history of neoliberalism. Oxford: Oxford University Press.

Herring, R.J. 2007. Stealth seeds: Bioproperty, biosafety, biopolitics. The Journal of Development Studies 43 (1): 130-157.

International Service for the Acquisition of Agri-Biotech Applications (ISAAA). 2017. Global status of commercialized biotech/ GM crops in 2017: Biotech crop adoption surges as economic benefits accumulate in 22 years. ISAAA Brief No. 53. ISAAA: Ithaca, NY.

Jakobsen, J. 2018a. Neoliberalising the food regime 'amongst its others': The right to food and the state in India. The Journal of Peasant Studies 46 (6): 1219-1239.

Jakobsen, J. 2018b. Towards a Gramscian food regime analysis of India's agrarian crisis: Counter-movements, petrofarming and Cheap Nature. Geoforum 90: 1-35.

Kannuri, N.K., and S. Jadhav. 2018. Generating toxic landscapes: Impact on well-being of cotton farmers in Telangana, India. Anthropology \& Medicine 25 (2): 121-140.

Kathage, J., and M. Qaim. 2012. Economic impacts and impact dynamics of Bt (Bacillus thuringiensis) cotton in India. Proceedings of the National Academy of Sciences of the United States of America 109 (29): 11652-11656.

Kaviraju, S., D. Kumar, N. Singh, and S. Kumar. 2018. A comparative study on socio economic impact of Bt cotton and non-Bt cotton farm households in Warangal District of Telangana State. International Journal of Current Microbiology and Applied Sciences 7 (5): 1561-1567.

Keck, M., H.-G. Bohle, and W.-P. Zingel. 2012. Dealing with insecurity: Informal business relations and risk governance among food wholesalers in Dhaka, Bangladesh. Zeitschrift Für Wirtschaftsgeographie 56 (1-2): 43-57.

Keck, M., and B. Etzold. 2013. Resilience refused wasted potentials for improving food security in Dhaka. Erdkunde 75-91.

Keck, M., and P. Sakdapolrak. 2013. What is social resilience? Lessons learned and ways forward. Erdkunde 5-19.

Khan, M.I., A.A. Khan, H.M.N. Cheema, and R.S.A. Khan. 2018. Spatio-temporal and intra-plant expression variability of insecticidal gene (Cry1Ac) in Upland Cotton. International Journal of Agriculture \& Biology 20: 715-722.

Kranthi, K.R. 2015. Pink bollworm strikes Bt-cotton. Cotton Statistics \& News 35: 1-6.

Kranthi, K.R. 2016. Fertilizers gave high yields Bt only provided cover. Cotton Statistics \& News 39: 1-6.

Kranthi, S., U. Satija, P. Pusadkar, R. Kumar, C.S. Shastri, S. Ansari, H.B. Santosh, D. Monga, and K.R. Kranthi. 2017. Non-Bt seeds provided by seed companies in India: Are they suitable as refuge for Bt-cotton? Current Science 112 (10): 1992-1993.

Kranthi, K.R., and G.D. Stone. 2020. Long-term impacts of Bt cotton in India. Nature Plants 6 (3): 188-196.

Krishna, V., and M. Qaim. 2012. Bt cotton and sustainability of pesticide reductions in India. Agricultural Systems 107: 47-55.

Krishna, V., M. Qaim, and D. Zilberman. 2016. Transgenic crops, production risk and agrobiodiversity. European Review of Agricultural Economics 43 (1): 137-164.

Kuchimanchi, B.R., D. Nazareth, R. Bendapudi, S. Awasthi, and M. D'Souza. 2019. Assessing differential vulnerability of communities in the agrarian context in two districts of Maharashtra, India. Climate and Development 11 (10): 918-929.

Kumar, R. 2015. Risking the farm: Will the smallholder survive? Economic and Political Weekly 50 (32): 27-31.

Lerche, J. 2013. The Agrarian question in Neoliberal India: Agrarian transition bypassed? Journal of Agrarian Change 13 (3): 382-404. 
Lerche, J. 2014. Regional patterns of agrarian accumulation in India. In Indian capitalism in development, ed. J. Heyer and B. HarrissWhite, 46-65. London and New York: Routledge.

Luxemburg, R. 2003. The accumulation of capital. London and New York: Routledge.

Matthan, T. 2021. The monsoon and the market: Economies of risk in rural India. PhD Dissertation, UCLA.

Marx, K. 1967. Capital, vol. I. New York: International Publishers.

McMichael, P. 2009. A food regime genealogy. The Journal of Peasant Studies 36 (1): 139-169.

Mohan, K. 2017. An area-wide approach to pink bollworm management on Bt cotton in India: A dire necessity with community participation. Current Science 112 (10): 1988-1989.

Mohan, K. 2018. Refuge-in-bag for Bt cotton. Current Science 114 (4): 726-727.

Mohan, K. 2020. SWOT analysis of refuge-in-bag for Bt-cotton in India. Current Science 119 (11): 1746-1750.

Mohan, K., and A.R. Sadananda. 2019. Success of refuge-in-bag for Bt-cotton hinges on good stewardship. Current Science 117 (5): 739-740.

Naik, G., M. Qaim, A. Subramanian, and D. Zilberman. 2005. Bt cotton controversy: Some paradoxes explained. Economic and Political Weekly 40 (15): 1514-1517.

Naik, V., S. Kumbhare, S. Kranthi, U. Satija, and K.R. Kranthi. 2018. Field-evolved resistance of pink bollworm, Pectinophora gossypiella (Saunders) (Lepidoptera: Gelechiidae), to transgenic Bacillus thuringiensis (Bt) cotton expressing crystal $1 \mathrm{Ac}$ (Cry1Ac) and Cry2Ab in India. Pest Management Science 74 (11): 2544-2554.

Najork, K., S. Gadela, P. Nadiminti, S. Gosikonda, R. Reddy, E. Haribabu, and M. Keck. 2021. The return of pink bollworm in India's Bt cotton fields: Livelihood vulnerabilities of farming households in Karimnagar District. Progress in Development Studies 21 (1): 68-85.

Nightingale, A.J., S. Eriksen, M. Taylor, T. Forsyth, M. Pelling, A. Newsham, E. Boyd, K. Brown, B. Harvey, L. Jones, R. Bezner Kerr, L. Mehta, L.O. Naess, D. Ockwell, I. Scoones, T. Tanner, and S. Whitfield. 2020. Beyond technical fixes: Climate solutions and the great derangement. Climate and Development 12 (4): 343-352.

Ong, A. 2007. Neoliberalism as a mobile technology. Transactions of the Institute of British Geographers 32 (1): 3-8.

Pal, S. 2002. Household sectoral choice and effective demand for rural credit in India. Applied Economics 14: 1743-1755.

Peck, J., and N. Theodore. 2007. Variegated capitalism. Progress in Human Geography 31 (6): 731-772.

Perelman, M. 2000. The invention of capitalism: Classical political economy and the secret history of primitive accumulation. Durham, NC: Duke University Press.

Qaim, M. 2003. Bt cotton in India: Field trial results and economic projections. World Development 31 (12): 2115-2127.

Raizada, A., S. Kumar, and P.K. Mishra. 2018. Vulnerability of rainfed areas in the Indian Deccan to climate change: Can we cope with the challenges? Indian Journal of Soil Conservation 46 (1): 1-10.

Ramamurthy, P. 2000. The cotton commodity chain, women, work and agency in India and Japan: The case of feminist agro-food systems research. World Development 28 (3): 551-578.

Ramasundaram, P., S. Vennila, and R.K. Ingle. 2007. Bt cotton performance and constraints in central India. Outlook on Agriculture 36 (3): 175-180.

Ramasundaram, P., A.K. Suresh, and R. Chand. 2011. Manipulating technology for surplus extraction: The case of Bt cotton in India. Economic and Political Weekly 46 (43): 23-26.

Ramprasad, V. 2019. Debt and vulnerability: Indebtedness, institutions and smallholder agriculture in South India. The Journal of Peasant Studies 46 (6): 1286-1307.
Rosa, H., K. Dörre, and S. Lessenich. 2017. Appropriation, activation and acceleration: The escalatory logics of capitalist modernity and the crises of dynamic stabilization. Theory, Culture \& Society 34 (1): 53-73.

Sadashivappa, P., and M. Qaim. 2009. Bt cotton in India: Development of benefits and the role of government seed price interventions. AgBioforum 12 (2): 172-183.

Scoones, I. 2008. Mobilizing against GM crops in India, South Africa and Brazil. Journal of Agrarian Change 8 (2-3): 315-344.

Shahbandeh, M. 2019. Cotton production by country worldwide in 2018/2019. https://www.statista.com/statistics/263055/cottonproduction-worldwide-by-top-countries/. Accessed 27 May 2021.

Stone, G.D. 2007. Agricultural deskilling and the spread of genetically modified cotton in Warangal. Current Anthropology 48 (1): 67-103.

Stone, G.D. 2011. Field versus farm in Warangal: Bt cotton, higher yields, and larger questions. World Development 39 (3): 387-398.

Stone, G.D., and A. Flachs. 2017. The ox fall down: Path-breaking and technology treadmills in Indian cotton agriculture. The Journal of Peasant Studies 45 (7): 1272-1296.

Subramanian, A., and M. Qaim. 2009. Village-wide effects of agricultural biotechnology: The case of Bt cotton in India. World Development 37 (1): 256-267.

Subramanian, A., and M. Qaim. 2010. The impact of Bt cotton on poor households in rural India. The Journal of Development Studies 46 (2): 295-311.

Tabashnik, B.E., and Y. Carrière. 2019. Global patterns of resistance to Bt crops highlighting pink bollworm in the United States, China, and India. Journal of Economic Entomology 112 (6): 2513-2523.

Tabashnik, B.E., L.R. Liesner, P.C. Ellsworth, G.C. Unnithan, J.A. Fabrick, S.E. Naranjo, X. Li, T.J. Dennehy, L. Antilla, R.T. Staten, and Y. Carrière. 2021. Transgenic cotton and sterile insect releases synergize eradication of pink bollworm a century after it invaded the United States. PNAS 118 (1): 1-5.

Taylor, M. 2018. Climate-smart agriculture: What is it good for? The Journal of Peasant Studies 45 (1): 89-107.

The Cotton Corporation of India (CCI). 2018. Area, production and productivity of cotton in India from 1947-48 onwards. Area, production and productivity of cotton (state-wise) 2008-09 onwards. Government of India. https://cotcorp.org.in/statistics. aspx? pageid=3\#cotton1. Accessed 27 May 2021.

Vasavi, A. R. 2012. Shadow space: Suicides and the predicament of rural India. ThreeEssays Collective: New Delhi.

Vasavi, A.R. 2014. Debt and its social entrapments. Women's Studies Quarterly 42 (1/2): 23-37.

Vasavi, A.R. 2020. The tiger and the tube well: Malevolence in rural India. Critical Asian Studies 52 (3): 429-445.

Veettil, P.C., V. Krishna, and M. Qaim. 2016. Ecosystem impacts of pesticide reductions through $\mathrm{Bt}$ cotton adoption. Australian Journal of Agricultural and Resource Economics 61 (1): 115-134.

Watts, M.J., and H.- Bohle. 1993. The space of vulnerability: The causal structure of hunger and famine. Progress in Human Geography 17 (1): 43-67.

Weichselgartner, J. 2016. Vulnerability as a concept in science and practice. In ATLAS Vulnerability and Resilience-Pilot version for Germany, Austria, Liechtenstein and Switzerland, ed. A. Fekete, and G. Hufschmidt, 18-21. Cologne \& Bonn.

Yadav, S., A.K. Godara, and V.P.S. Yadav. 2018. Impact of Bt cotton production technology in Haryana. Indian Research Journal of Extension Education 18 (2): 66-71.

Publisher's Note Springer Nature remains neutral with regard to jurisdictional claims in published maps and institutional affiliations. 
Katharina Najork is a doctoral researcher at the Institute of Geography at the Georg-August-University, Göttingen. She is a research associate in the project "Politics of knowledge and non-knowledge: Agricultural biotechnology in India", funded by the German Research Foundation (KE 1983/3-1). Her research interests include agricultural biotechnology, political economy, rural livelihoods, vulnerability studies, policy mobilities.

Jonathan Friedrich is a doctoral candidate at the Leibniz Centre of Agricultural Landscape Research (ZALF) and at the Institute of Geography at the University of Göttingen. His research interests include drivers and barriers of social-ecological transformations in the agrifood-system, bioeconomic innovations and approaches, and issues of environmental justice.

Markus Keck is Chair for Urban Climate Resilience at the Centre for Climate Resilience, University of Augsburg. He is the PI of the project "Politics of knowledge and non-knowledge: Agricultural biotechnology in India", funded by the German Research Foundation (KE 1983/3-

1). His research interests include agri-food studies, climate resilience, socionatures, speculative futures, and urban infrastructure. 